\title{
Copenhagen Business School
}

From the SelectedWorks of Elisabeth Brooke Harrington

July, 2016

\section{Trusts and Financialization}

Elisabeth Brooke Harrington 


\title{
Article
}

\section{Trusts and financialization}

\section{Brooke Harrington*}

Department of Business and Politics, Copenhagen Business School, Copenhagen, Denmark

${ }^{*}$ Correspondence: bh.dbp@cbs.dk

\begin{abstract}
This article identifies trusts as a legal structure associated with the global spread of financialization. Although trusts originated in Medieval England, they have acquired a new significance in contemporary finance by virtue of their advantages in terms of profit maximization and capital mobility. As a result, trusts have become common in contemporary structured finance for corporations, in addition to their traditional functions as estate planning and asset protection vehicles for high-net-worth individuals. This article specifies three ways in which the trust structure has facilitated the global spread of financialization: by privileging the rentier-investor within the world economy; by perpetuating a distinctively Anglo-American approach to finance internationally; and by increasing the autonomy of finance vis-à-vis the nation-state. This study shares the primarily descriptive and conceptual intent of Krippner's work on financialization, but extends it in two ways: by comparing trusts to the betterknown corporate form of organizing financial activity, and by showing how private capital is implicated in the financialized economy alongside corporate wealth.
\end{abstract}

Key words: financialization, wealth, elites, financial services

JEL classification: Z1 economic sociology, N2 financial markets and institutions

'The trust is an effort to escape from the ever-deepening and ever-recurrent crises in capitalism. It is the confession of the upper middle class-the class that has most used the trust-that the contradictions in capitalism cannot be resolved' (Franklin, 1933, p. 475).

\section{Introduction}

Just as financialization has been identified as a response to recurring crises in capitalism (Arrighi, 1994; Krippner, 2011), so has the trust. Though Franklin's observations in the epigraph above were made in the context of the Great Depression, and Arrighi's (1994, p. 1) followed the world economic crisis of the 1970s, both refer to a long-standing pattern of wealth accumulation being wiped out by recurrent economic contractions. The trust, as a 
legal structure for holding assets, has proven to be a useful tool for protecting wealth from these crises, and for allowing capital to grow in spite of them (Harrington, 2016). Trusts are often used to structure international finance (Langbein, 1995) as well as private wealth, although they have been overlooked in the financialization literature in favor of corporations (Krippner, 2011).

Trusts are a type of asset-holding structure that facilitates the profit maximization and international capital mobility characteristic of financialization (Krippner, 2005, p. 203). Although trusts originated in Medieval England (Harrington, 2012a), their exceptional 'generality and elasticity' (Maitland, 1936, p. 129) has allowed them to survive the transition from feudalism to capitalism, contributing and adapting to the global spread of financialization. As Krippner (2011) has documented, economies that once were grounded in making and selling things have shifted from creating to distributing wealth: what another scholar of financialization calls 'mov[ing] wealth from one hand to another' (Mukunda, 2014). This shift, which took hold in the USA and other major world economies in the last quarter of the 20th century (Krippner, 2005), demanded tools to move wealth internationally with minimal cost and effort. Trusts offered a ready-made legal structure to achieve these ends (Beaverstock et al., 2013). Their distinctive characteristics permit the nearly frictionless global movement of capital, maximizing profits by minimizing compliance costs and tax obligations, as well as by sheltering assets from tax authorities and creditors.

As a result, trusts have contributed to the autonomy of finance relative to control by states. For both private individuals and firms, the freedom from taxation and many forms of regulation make trusts a 'privileged site of accumulation' (Krippner, 2005, p. 181)—a position in the economy that facilitates the ease and speed of amassing capital. As a result, trusts expanded from their historical uses in the service of high-net-worth individuals, to application in large international financial transactions among corporations (Parkinson, 2008). Bond issues, mutual funds, asset securitization and many other pillars of contemporary financial capitalism are structured by trusts (Langbein, 1995).

By examining trusts' role in private and corporate finance, this article will argue that they contribute to financialization in three significant ways: by consolidating the power of the investor as the central figure in the global economy; by facilitating the dominance of Anglo-American finance; and by increasing the autonomy of finance from the nation-state system. Like Krippner's (2005) original work on financialization, this article contributes descriptive and conceptual insights. It also extends understanding of financialization in two ways: by comparing the trust relative to the better-known corporate form, and by showing how private capital is implicated in the world financial system alongside corporate wealth. Secondary data suggest that the private capital held in trusts by Americans amounts to at least \$16 trillion, and that American corporate trusts hold even more (Langbein, 2004; Wolff, 2012; Saez and Zucman, 2014). While these estimates are provisional, they suggest a phenomenon deserving of more scholarly attention.

Finally, this study of trusts will follow Arrighi (1994) in taking an international perspective on financialization. Since trusts, both in private and corporate use, are often deployed in transnational contexts, the analysis offered in this article will contribute to ongoing debates in social science about modes of economic globalization, which Krippner (2005, p. 202) calls 'one of the most vexed issues in all of social science'. Specifically, the article will review the international evolution and applications of the trust to show that what 'globalization skeptics' interpret as a lack of coordination in the financial system-and therefore as a weak 
challenge by finance to the power of the state-misses the development of a different kind of coordination: one based not on hard law and formal institutions, but on the diffusion of structures like the trust and practices surrounding their use. Instead of producing the global convergence in financial regulations that many expected (Deeg, 2012), contemporary finance has taken a 'divide and conquer' approach to national laws, growing through exploitation of the gaps and conflicts. That financialization has assumed a different form than anticipated is due partly to the capital mobility and profit opportunities facilitated by the use of the trust structure. Rather than state-led coordination, 'globalized localisms' (Jensen and Santos, 2000) like the trust link an international system of finance through a largely unregulated structure for transferring and accumulating capital.

\section{Toward a sociology of trusts}

This section will describe the basic conceptual features of trusts, as well as some features of special interest to scholars of economic sociology and financialization. As Gerring (2012) has pointed out, this work of conceptualization makes an important and distinctive contribution to knowledge, though it is often undervalued. Within the natural sciences, naming, identifying and classifying have long been recognized as essential to the advancement of research. Such work is particularly necessary for a sociology of trusts, because they are relatively unknown in the scholarly literature, outside of legal studies (e.g., Hofri, 2015). As the following sections will show, trusts can potentially be of interest for scholars in a wide variety of fields, including economic sociology, the sociology of law and political economy. This study will focus on financialization as an area where all those domains of research intersect.

Trusts are asset-holding structures that maximize capital mobility and profits through what one scholar calls a set of 'tricks' for 'manipulating facets of ownership' (Moffat, 2009, p. 5). Trusts acquire this power as a result of two defining features: the bifurcation of ownership, and a distinctive legal status. A trust is created when a person (known as the trustee) accepts assets from another person (the settlor), for the benefit of a third person (the beneficiary). ${ }^{1}$ In this arrangement, legal ownership and responsibility for the assets pass from the settlor to the trustee, but the use and enjoyment of the assets go the beneficiaries. Thus, ownership is split into two components: legal and beneficial. The trustee has special obligations, including the requirement to act as a 'fiduciary', meaning to own and manage the trust assets in the best interests of the beneficiaries, rather than for personal gain (Langbein, 1995). ${ }^{2}$

In addition to divided ownership, the other conceptually distinctive aspect of trusts is their status and treatment in law. Unlike other asset-holding structures, such as foundations or corporations, trusts are not separate legal entities. Instead, trusts are private relationships-recognized by the laws of many countries, but not possessed of a 'legal personality' in their own right. This has a number of consequences; for example, a trust cannot be sued or go bankrupt, as legal entities like corporations can.

1 Here, 'person' can refer either to a natural person (a human being) or a legal person, such as a corporation.

2 A body of law has arisen to protect the interest of beneficiaries to trusts. Trustees are legally bound to manage the assets in the best interests of the beneficiaries, and to distribute any proceeds of those assets according to the instructions set out when the trust was founded. Trustees are forbidden from using or benefitting from the assets in any way. 
The legal status and 'tradition of the trust as a personal relationship' (Stebbings, 2007, p. 7) is so distinctive that for centuries, trust-related disputes were not tried in law tribunals. Instead, they were adjudicated by religious leaders in ecclesiastical courts (Outhwaite, 2006). This is because, for most of their history, trusts were seen as governed by interpersonal moral obligation, in which a 'duty of loyalty replaces contractual terms' (Easterbrook and Fischel, 1993, p. 427). This conceptualization had practical consequences: for example, trusts were exempt from the usual requirement of 'consideration' (i.e., payment) to establish a binding legal relationship (Langbein, 1997). In fact, trustees were barred for centuries from accepting compensation for their work (Hall, 1973); instead, they were expected to undertake the responsibilities of legal ownership 'as a burden upon the[ir] honor and conscience' (Sanders, 1791, p. 194).

In sociological terms, trusts are governed by the logic of the gift rather than the logic of compensation (Zelizer, 1996). This is also recognized in the law, where the trust structure is conceptualized formally as 'a gift, projected on the plane of time' (Rudden, 1981, p. 610). This gift, in this case, is made by the settlor to the beneficiary; since it is not a one-time gift, but one intended to unfold over time (traditional private trusts endure for just over 100 years), the transmission process is administered by the trustee. Although the law has changed to permit payment of trustees as the norm, they are still required to enact the logic of the gift through their fiduciary responsibilities, which entail ownership rights exercised purely for the benefit of others.

The embeddedness of trusts in interpersonal relationships, along with their ongoing links to the gift economy, are key to their sociological interest as well to their practical functioning. For example, among the most highly prized features of trusts in contemporary practice is that-since they are treated legally as private gift relationships-they are very lightly regulated and afford near-complete privacy to the parties involved. Since trusts are not separate legal entities, their existence is not publicly recorded; there is no equivalent of a public corporate register for trusts. This creates strategic obscurity and uncertainty with respect to asset ownership. In fact, trusts 'shroud assets in cast-iron secrecy' (Shaxson, 2011, p. 42), make it very difficult to impose responsibility for any costs or legal restrictions connected to the assets. These include limitations on the movement of the assets, as well as the payment of creditors, taxes, or court-ordered fines and settlements. Thus, one legal scholar offered the following simple definition: 'A trust is a device for enabling one to enjoy ... the benefits of ownership without subjection to all the duties and liabilities resulting from ownership' (Scott, 1922, pp. 457-458).

The trust structure is deployed in the contemporary financialized era as a key component in a global 'shell game' (Fitch, 2003), in which lawyers and finance professionals orchestrate transnational capital movements 'in a fashion that operates within the letter but against the spirit of the law' (Moffat, 2009, p. 113). To illustrate the scope of these capital movements, consider the following 'typical client' scenario presented in a training manual for professional trustees:

the proposed settlor [the person putting assets into trust] is a Brazilian national, but has been living in Canada for the last 15 years where he considers his permanent home to be. The trustees are to be a trust institution in the Cayman Islands with a professional protector situated in the Bahamas. It is intended that the trust assets will comprise shares in two underlying companies: the holding company of the settlor's Latin American business empire is incorporated as an exempt company in Bermuda; and an IBC incorporated in BVI holding a portfolio of stocks and 
shares. The discretionary beneficiaries [the people entitled to use of the trust assets, at the trustees' discretion] comprise a class of persons who reside throughout Europe and South America. (Parkinson, 2005, p. 220)

This example, in which trust activity is spread over three continents and more than half a dozen countries, suggests how trusts are used to facilitate the intensive capital mobility requirements of private and corporate wealth in a globalized economy.

Because trusts are not publicly registered and are subject to very few legal controls, they make it possible to move large sums of capital around the world at very low cost compared to more highly regulated structures, such as corporations. As one legal scholar put it recently, "the trust performs its "tricks" with property better, and has stronger legal reinforcement, than other competing legal institutions' (Moffat, 2009, p. 5). This means fewer transaction and compliance costs attach to assets held in trust, which contributes to profit maximization—another key feature of financialization (Krippner, 2005, p. 200).

The distinctive way that trusts organize asset ownership has made them useful not only for wealthy individuals, but for corporations themselves (Langbein, 1997). For example, a common function of trusts in the global financial system is to act as a container for corporate shares; this has been the organizational structure underlying mutual funds since their inception in the late 1700s (Reid, 2006). Trusts have also become a tool of structured finance for corporations, underlying bond issues and making asset securitization possible (Langbein, 1995). On a global scale, 'trusts, and especially purpose trusts, play an increasingly important part in international financial transactions' (Parkinson, 2005, p. 335). (See Appendix for examples.)

Following Gerring (2012), Figure 1 offers a simple typology of trust structures to illustrate their primary uses in both corporate and private contexts. As the figure indicates, there are two primary subtypes of trusts: private express trusts, which are used exclusively by individuals for objectives such as estate planning and asset protection; and purpose trusts, which are used both by individuals and firms, to achieve goals ranging from philanthropy and family business protection to the creation of complex collective investments. The offshore purpose trust, in particular, forms the organizational basis for many mutual funds, bond issues and asset securitization projects.

As the figure indicates, offshore financial centers play a particularly important role in linking trusts to financialization. The laws of many jurisdictions-such as the Cayman Islands and the Cook Islands, mentioned in the figure-have been tailored specifically to maximize the financial benefits that trusts can provide to firms and individuals. In particular, the split-ownership concept underlying trusts has been magnified in economic significance through the use of offshore legislation. To maximize profits through minimizing transaction and compliance costs, a common strategy is to give legal ownership of assets to trustees based in offshore locales where tax and regulatory expenses are negligible to nonexistent. As a matter of international law, trust assets are only subject to regulation and taxation in the jurisdiction where the legal owner lives. So trustees strategically base themselves in countries that offer the lowest compliance costs and tax rates. Jurisdictions all over the world compete to offer the most attractive regimes (Economist, 2013), but historically the dominant player has been the UK, along with its territories and former colonies.

Using trusts in this way, a Russian national living in London can benefit from a multimillion-dollar portfolio of US stocks held in a Cayman Islands trust without paying tax on the 


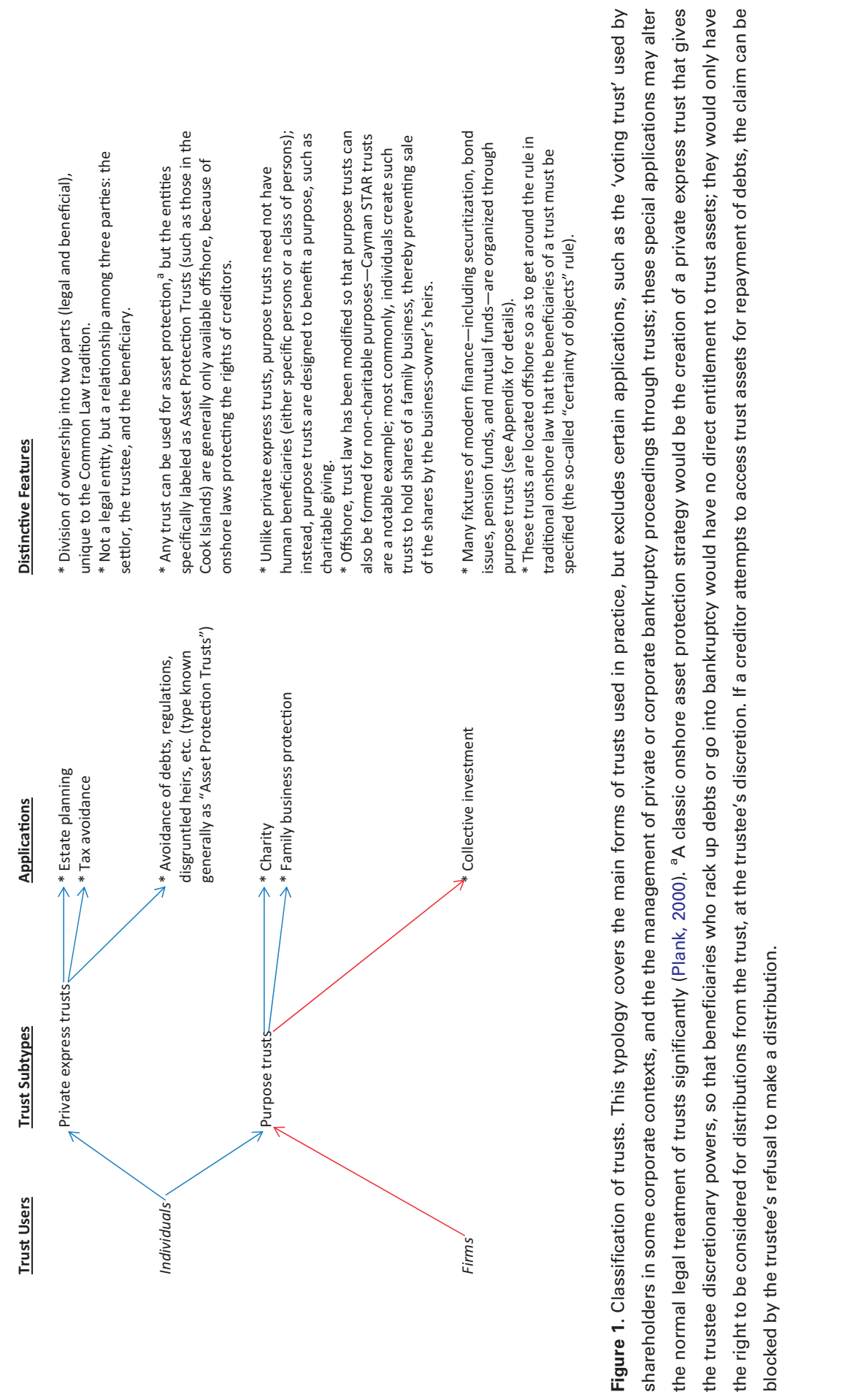


profits, because he is not the legal owner of the assets. ${ }^{3}$ The trustee is the only one liable for any legal obligations associated with the portfolio, and since the Caymans imposes no tax on capital gains or income, profits can flow unimpeded to the beneficial owner in London. For the same reason-divided ownership — the trust assets are untouchable by the Russian's creditors, legal heirs and divorcing spouses (Parkinson, 2005; Harrington, 2015). Finally, should that Cayman Islands trust be threatened by an unwanted obligation, or if a more attractive taxation or regulatory regime becomes available elsewhere, the trust form makes it easy to move the assets with minimal cost from one jurisdiction to another. ${ }^{4}$ The following sections elaborate on these and other features of the trust that hold particular interest for sociologists.

\subsection{Comparing trusts and corporations as privileged sites of accumulation}

As instruments for accumulating and growing capital, trusts predate the better-known corporate form of organization. In fact, before the corporate form became widely available in the mid-19th century, many industrial and commercial enterprises during the previous 100 years were organized through trusts; these were known as 'deed of settlement' firms (Moffat, 2009). By the 20th century, corporations became the dominant form of business organization by offering limited liability and the convenience of a separate 'legal personality', which could enter into contracts and obtain loans. But trusts have remained the preferred vehicle for collective investment, as well as estate planning and private asset protection (see Appendix for detailed examples).

The light regulatory burden imposed on trusts has been key to their ongoing appeal in the contemporary financial era. These qualities make trusts highly adaptable instruments for transferring capital, particularly on an international scale. Since so few rules apply to them, trusts can be tailored to a wide variety of private and commercial purposes. In contrast, corporations have historically attracted considerable regulatory attention due to their longstanding connection with fraud and economic crises (Chancellor, 1999; Harrington, $2012 \mathrm{~b}$ ). Regulation of firms has increased during the era of financialization due in part to the greater frequency of such crises (Krippner, 2011). But trusts largely avoided such regulatory scrutiny by virtue of their status as private relationships; unlike corporations, regulating trusts was not seen as a matter of public interest. ${ }^{5}$ Thus, while corporations are 'encumbered with restrictions of a regulatory character, designed to protect creditors and shareholders ... the commercial trust continues to offer the transaction planner nearly unlimited flexibility in design' (Langbein, 1997, pp. 184-185). Table 1 compares the two modes of organizing capital.

3 Beneficiaries are liable to pay tax on the distributions they receive from trusts, but there are many ways to make those distributions tax-free-for example, by labeling them as 'loan repayments' to the beneficiaries.

4 This power to move the situs of the trust must be specifically stated in the trust instrument-the document that sets out the blueprint for the trust. This power, known as a 'flee clause', is commonly included in contemporary trust instruments, particularly for offshore use.

5 Those familiar with American history may find this confusing, since in the late 19th and early 20th centuries, much public policy was focused on 'trust busting'. However, this term was a misnomer in that it actually referred to corporate monopolies, some of which—like Standard Oil—used trusts as part of their structure. Despite the terminology, the policy agenda was not set against trusts per se, but rather against the monopolies (Dudden, 1957). 
Of course, these qualities of elasticity, generality and design flexibility are only realized through the intervention of social agents-in particular, the financial and legal professionals who deploy trusts as part of their everyday practices. These professionals take on the duties of trustees, and strategize with clients to determine what assets should be held in trust, and under what country's laws a trust should be placed. This points up an important distinction: trusts did not create financialization. Rather, experts found in trusts a ready-made tool to accomplish some of the tasks financialization requires, such as maximization of capital mobility and profits with minimum regulatory friction. This use of trusts thrives and depends on the gaps and conflicts among national legal systems, creating strategic disarray rather than convergence (Harrington, 2016).

Thus, while trusts have some disadvantages, including lack of the worldwide legal recognition accorded to corporations, they are in many ways an example par excellence of what Krippner calls a 'privileged site of accumulation' (2005, p. 181). While Krippner herself does not elaborate on this concept at any length, she and others (e.g., Labban, 2010) have used it to refer to the advantages that accrue to entities adapted to profit-making rather than production. The 'privilege' consists of the ease and rate of capital accumulation that certain structures or positions within the economy make possible.

As an example, moving corporate assets into trusts saves firms a great deal in taxes and regulatory compliance costs, while also allowing them to access new capital more easily. Trusts allow firms to move debts 'off balance sheet', making the companies more attractive to investors and lenders (Bentson, 2006). This is because the trust creates a 'firewall' of privacy between the firm and the liabilities (such as a failing business unit) that it places in trust: since trusts are unregistered entities, it becomes impossible to link the original corporate owner to the liability. Enron offers us one of the most famous recent example of this use of trusts as a privileged site of accumulation: by creating just two offshore trusts to hide its liabilities, Enron was able to inflate its Year 2000 incoming cash flow by $\$ 1.1$ billion and conceal more than $\$ 3.3$ billion in debt-both of which enhanced the attractiveness of the firm to investors and lenders. This allowed the firm, which was in reality hemorrhaging money, to raise $\$ 3.8$ billion in additional financing (Batson, 2003). Despite Enron's demise, the advantages offered by trusts continue to make them very attractive to corporations. Many firms now make regular use of trusts as part of their organizational structure (Langbein, 1997).

Thus, while the corporate form has received bulk of scholarly attention as a site of privileged accumulation, the privileges attendant upon the use of trusts have not received as much recognition as they deserve. Specifically, four factors idenfitied in Table 1 distinguish trusts as providing unique advantages in the accrual of economic and political power. First, trusts are exempt from an entire level or realm of taxation: while corporate income is taxed twice-first at the corporation level, and then again when distributed to shareholders-trust assets are only taxed once, when distributed to beneficiaries (and even that may be avoidable). ${ }^{6}$ In addition to this privileged tax status, assets held in trust enjoy a degree of protection from legal judgments and other claims that corporations do not; thus, corporations can go bankrupt, but trusts cannot. Third, since trusts are far more lightly regulated than corporations, they incur much lower compliance costs. These lower costs may be one reason that the fortunes of the wealthy, who are the primary users of private trusts, grow at a faster rate

\section{See note 3.}


Table 1. Comparing corporations and trusts

\begin{tabular}{|c|c|c|}
\hline & Corporations & Trusts \\
\hline Primary purpose & $\begin{array}{l}\text { Trading and commerce; } \\
\text { maximization of shareholder } \\
\text { value }\end{array}$ & $\begin{array}{l}\text { Holding and distributing wealth in } \\
\text { the best interests of beneficiaries }\end{array}$ \\
\hline Ownership & $\begin{array}{l}\text { Shareholders, who pay for shares and } \\
\text { may lose the capital they invest }\end{array}$ & $\begin{array}{l}\text { Divided between beneficiaries and } \\
\text { trustees; beneficiaries pay } \\
\text { nothing, while trustees are } \\
\text { compensated for risk and labor }\end{array}$ \\
\hline Legal status & $\begin{array}{l}\text { Separate legal entity (juris person); } \\
\text { recognized worldwide }\end{array}$ & $\begin{array}{l}\text { Not a legal entity, but a private } \\
\text { agreement; recognized only in } \\
\text { common law jurisdictions }\end{array}$ \\
\hline Management & Directors & Trustees \\
\hline Tax liability & $\begin{array}{l}\text { Income taxed twice: once at } \\
\text { corporate level annually, and } \\
\text { again when distributed to } \\
\text { shareholders }\end{array}$ & $\begin{array}{l}\text { Income taxed once, when distributed } \\
\text { to beneficiaries; otherwise accrues } \\
\text { tax-free }\end{array}$ \\
\hline Asset protection & $\begin{array}{l}\text { Corporate assets can be attached by } \\
\text { creditors and litigants; } \\
\text { corporation can go bankrupt, } \\
\text { leaving shareholders with } \\
\text { nothing }\end{array}$ & $\begin{array}{l}\text { Trust assets inaccessible to creditors } \\
\text { and litigants; trusts cannot go } \\
\text { bankrupt }\end{array}$ \\
\hline Privacy & $\begin{array}{l}\text { Corporations must be publicly } \\
\text { registered and disclose names of } \\
\text { directors }\end{array}$ & $\begin{array}{l}\text { No registration; name of trustee may } \\
\text { be public record in some } \\
\text { jurisdictions, but identities of } \\
\text { beneficiaries remain confidential }\end{array}$ \\
\hline Compliance costs & $\begin{array}{l}\text { Required reporting (income } \\
\text { statements, audits, etc.), plus } \\
\text { tight limits on liquidity and } \\
\text { distributions }\end{array}$ & $\begin{array}{l}\text { Few to no reporting requirements or } \\
\text { limits on liquidity and } \\
\text { distributions }\end{array}$ \\
\hline Ease of migration & $\begin{array}{l}\text { More difficult and costly to move a } \\
\text { corporation from one jurisdiction } \\
\text { to another }\end{array}$ & $\begin{array}{l}\text { Relatively easy and low cost to move } \\
\text { a trust from one jurisdiction to } \\
\text { another ('flee clauses') }\end{array}$ \\
\hline
\end{tabular}

than average. In the USA, for example, the wealth of the top $1 \%$ has grown at an annual rate $30 \%$ greater than the national average for more than 35 years (Wolff, 2012).

These three factors contribute to economic privilege by allowing assets in trust to accumulate more quickly, and with fewer threats than assets held in a corporate structure. Added to this is the fourth and final distinction that gives trusts an edge over corporations as a site of privileged accumulation: privacy. While corporations must be publicly registered, and disclose the names of their directors-as well as the names of their shareholders, in some jurisdictions-trusts are completely unregistered entities in all but a few countries, and the identities of beneficial owners are everywhere treated as closely guarded secrets (Conn, 2015). This provides both economic and political privileges. Economically, privacy increases freedom from the rule of law: when the true beneficial owners of assets cannot be identified, they cannot be taxed or regulated (Shaxson, 2011). Politically, the privacy surrounding 
trusts provides protection from public accountability, allowing individuals to accumulate not just wealth but power through means such as contributions to political campaigns and lobbying activities-all anonymously, using the trust structure to shield their identities. The implications of such strategic uses of the trust, both by corporations and private individuals, will be elaborated upon in Section 3.

\subsection{Quantifying what is known about trusts}

The lack of regulation and registration of trusts makes it impossible to know the total number of trusts worldwide, or the value of the assets they contain (Chester, 1982; Sharman, 2006). This is part of a more general problem associated with research on elites: the wealthy are almost totally excluded from publicly available datasets (Kopczuk and Saez, 2004). Surveys 'systematically underrepresent the rich and do not reflect the holdings of the superrich' (Davies et al., 2008, p. 17). Indeed, the members of the Forbes 400 are explicitly excluded even from datasets that oversample on wealth, such as the Survey of Consumer Finances (Budría et al., 2002). Some individuals even pay to be left off of the Forbes 400 list, in order to protect their privacy even further (Demick 1990; Kolhatkar 2016).

Such individuals-along with a growing number of firms-value trusts all the more highly as the secrecy and light regulation that trusts afford become increasingly rare. In other domains of finance, transparency is becoming the norm (Seabrooke, 2011); the trust is very much an outlier in this regard. But the same features that make trusts so attractive for users also make them very difficult to study. With few exceptions, data that would allow us to quantify trusts' significance in the international political economy are carefully protected behind legal barriers.

Recent interest in stratification has brought to light how the 'politically dangerous' information needed to estimate the extent of trust assets and other sources of wealth inequality has been obscured (Pinçon and Pinçon-Charlot, 1998, p. 8). For example, professional trustees can face civil or criminal penalties for divulging information about trust assets or beneficiaries. Even if they believe the trusts they manage are linked to illegal activities, trustees are subject to 'strict confidentiality statutes, which not only ensure that the disclosure of client information to third parties is actionable in a civil court, but also render the offending professional liable to a fine and/or imprisonment for a criminal offense' (Parkinson, 2004, p. 9).

The data that occasionally do come to light on trusts generally emerge from two sources. The first is lawsuits, which usually generate public trial records in which the magnitude and structure of wealth held in trust can be exposed. Examples include the Pritzker family of Chicago: a suit launched by a beneficiary accusing the trustees of apportioning trust assets unfairly laid out for public view the family's \$15 billion fortune, which was held in 60 companies and 2500 trusts (Jaffe and Lane, 2004). In the corporate arena, a prosecution by the US Securities and Exchange Commission brought to light a 'maze' of dozens of offshore trusts, located primarily in the Cayman Islands and the Isle of Man, used by brothers Sam and Charles Wyly to hide $\$ 1$ billion worth of stocks in their family firm; this structure enabled the brothers to evade regulations against insider trading and pocket $\$ 550$ million in capital gains, tax free (Guinto, 2013; Savchuck, 2014).

The second major data source on trusts is theft. In recent years, there have been a few high-profile cases of employees from offshore banks and other wealth-management firms stealing and selling databases of trust beneficiaries to governments and journalists. This includes private account information stolen from organizations in Liechtenstein, 
Luxembourg and parts of the Caribbean (Bowers, 2014; Gauthier-Villars and Ball, 2010). Most recently, an anonymous source leaked 11.5 million files encompassing nearly 40 years' worth of trust creation and management by the Panama-based firm Mossack Fonseca. These files revealed billions held in offshore trusts by business leaders, celebrities and politicians-a virtual 'who's who' of the global elite. This included several billion held in offshore trusts for the benefit of Russian President Vladimir Putin. According to anticorruption activist Alexei Navalny, the leak reveals only a small fraction of the trust assets beneficially owned by Putin: 'The reaction in Russia is: 'Ha, ha, they only found two billion?' It's petty cash for personal expenses' (Seddon, 2016). It is unlikely that these claims will be substantiated with further evidence of Putin's trust holdings. And this suggests the problem with trust data gleaned from leaks and lawsuits: they are often anecdotal and unsystematic. Scholarly research can use them only as illustrations.

Notable exceptions to this pattern of data unavailability on trusts come from the painstaking calculations of a handful of economists. In particular, Wolff (2012) and Zucman (2015) have found ingenious ways to estimate portions of the information that would allow an educated guess about the extent of assets held in trust, at least within the USA. Recent work by Saez and Zucman (2014) suggests that private trust assets average $\$ 5.2$ million for American households in the top $1 \%$ by wealth; according to Wolff (2012), the next $9 \%$ of households hold trust assets averaging \$949 800 in value. Compare this to Sitkoff and Schanzenbach's (2005) estimate of $\$ 1$ million as the average value of a domestic private trust account. The apparent upswing in trusts' asset value, particularly among the households at the $1 \%$ level, is consistent with the larger trend of dramatic increases in the fortunes of the wealthiest American households, particularly since the financial crisis of 2008 (Saez and Zucman, 2014).

Since the top $10 \%$ of households own more than $90 \%$ of all private trust wealth in the United States (Wolff, 2012), we can use data from this group to make a rough estimate of the asset value these trusts represent. By combining the findings from Saez and Zucman (2014) with those of Wolff (2012), it appears that Americans' private trust wealth amounts to just over $\$ 16$ trillion. $^{7}$ This is roughly equivalent to the GDP of the USA-a relationship between household wealth and GDP consistent with trends going back decades (Piketty and Zucman, 2014). While this figure for the USA is speculative, it is the best available for now, and seems to square with other information we have on the broader parameters of private wealth. For example, recent estimates suggest that there is $\$ 46$ trillion in private wealth in

7 Specifically, this involves using Wolff's (2012) findings on the percentage of assets held in trust by the top $10 \%$ of US households, then combining them with estimates from Saez and Zucman (2014) on the total number of those households in the top $10 \%$, and the average wealth of those households, excluding their primary residences (this is standard for estimations of net worth). Saez and Zucman draw from the same data source as Wolff (the US Survey of Consumer Finances), but add data from the Forbes 400 survey of American's wealthiest families. Since the Survey of Consumer Finances is known to under-represent the very wealthiest families in the US (Kennickell, 2009), this additional dataset enables Saez and Zucman to create a more accurate estimate of household wealth at the top of the spectrum. However, their findings must still be combined with those of Wolff in order to estimate the total amount of private wealth held in trust by Americans, since only Wolff calculates the percentage of household wealth that is actually held in trust. While Saez and Zucman acknowledge the significance of trusts as a source of wealth, they do not split out household assets in sufficient detail to estimate what percentage of that wealth is held in trust, as opposed to other forms. 
the USA (Boston Consulting Group, 2015); the calculation proposed in this article suggests that about $35 \%$ of that is held in trust.

However, at least two key questions remain unanswered about the position of trusts in the global economy. First, the kinds of estimates provided by Wolff (2012), as well as by Saez and Zucman (2014), are unique to the USA: there are no equivalent data for other countries as yet. This work is very much on the cutting edge of research in economics and finance. Second, it is unclear how much corporate wealth is held in trust. Experts in corporate uses of trusts claim that 'The aggregate assets of these commercial trusts now dwarf the assets held in personal trusts by a ratio of something like 20-to-1' (Langbein, 2004, p. 57). However, this seems unlikely, since it implies a total value of at least $\$ 320$ trillion for commercial trusts, which exceeds by a wide margin estimates of the $\$ 225$ trillion total value of corporate wealth worldwide (Lund et al., 2013).

As a result, it is difficult to put a precise quantity on trusts' significance within a financialized economy. The best data available for now suggest that the aggregate of private and corporate wealth held in trusts runs into the tens of trillions of dollars and exceeds the GDPs of the world's largest economies. Until better data are available, this study must restrict itself to non-quantitative means of suggesting the role trusts play in the world economy.

\section{Trusts and financialization}

Building on the conceptualization of trusts offered in the previous section, this article will argue that these structures contribute to financialization in three significant ways: by consolidating the power of the investor as the central figure in the global economy; by maintaining and enlarging the Anglo-American character of finance worldwide; and by increasing the autonomy of finance from the nation-state system.

In the first instance, trusts consolidate the power of investors in part by making certain kinds of large-scale investment legally and economically feasible. Thus, they are the preferred organizational form for mutual funds, pension funds and other forms of institutional investment. Furthermore, the patchwork of data available on private trusts indicates that the vast majority of their assets consist of stocks and bonds. Both corporate and individual investors reap distinctive profit-making opportunities and protections by using trusts, as opposed to alternative structures.

In the second case, trusts are linked inextricably to the ways in which the AngloAmerican approach has left its mark on financialization (van der Zwan 2014). We see this in two ways. As part of British imperial expansion, the Common Law framework was imposed on the colonies; the trust concept was among the most 'distinctive' (Maitland 2011 [1909]) elements of that transplanted legal system. The trust remains as a legacy in the modern law of almost all the former colonies, including the major tax havens of the world. Even in countries that were never British colonies, and never adopted the Common Law tradition, there is increasing recognition and even legal adoption of trusts; this has been driven by pressure in those countries to integrate with a global financial system dominated by the AngloAmerican approach. In other words, trusts are both an expression and a facilitator of the essentially Anglo-American character of financialization.

In the third case, trusts loosen the constraints of the law on assets and their owners. The privacy provided by trusts and the light regulatory burden they enjoy allow assets to move largely unimpeded from jurisdiction to jurisdiction; owners (beneficial or legal) are free to 
'shop' for the most hospitable legal regime for those assets. Thus, the trust has enabled finance itself to become hyper-mobile, enjoying a large measure of autonomy from the laws of any particular nation-state.

\subsection{Economic dominance of investors}

A defining characteristic of financialization is the placement of investors, rather than producers, at the center of the world economy (van der Zwan, 2014). Trusts facilitate this by providing investors with special freedoms from losses and legal constraints. One of the most significant manifestations of power under a financialized economic regime is the ability to reap the benefits of investment without being subject to the same degree of risk and responsibility as others (Sayer, 2015). Investors grow in power to the extent that they can capture the advantages of participating in financial markets (particularly the profits) while protecting their accumulated wealth from losses, taxes and debts. In the financialized era, trusts have become 'privileged sites of accumulation' (Krippner, 2005, p. 181), in which privilege is manifested not only by the ease and speed of profit-making, but by exemption from risk and obligation.

The uses of trusts to profit from investments without being subject to statutory levels of taxation came to widespread attention during the 2012 presidential candidacy of Mitt Romney. Romney faced public opprobrium when he disclosed that he had paid an effective tax rate of just $13.9 \%$, instead of the $39.6 \%$ rate prescribed by law for his level of income. The source of his income-a $\$ 250$ million fortune, mostly in the form of financial securities-was protected from tax by being scattered across seven trust structures located around the globe, from Australia to the Cayman Islands (Dwyer, 2012).

Romney's case is the norm rather than the exception, at least in terms of the content of his trust funds: of the $4.3 \%$ of American households who have assets in private trusts, most $(88.5 \%)$ of their trust assets consisted of stocks and bonds; the remainder was held in real estate and other investments (Bricker et al., 2014). In contrast, the wealth of the other $90 \%$ of households lies primarily in home ownership. So, while the lower $90 \%$ of American households use their money to build equity in their homes, which is generally a slow and modest way to build wealth, the top $10 \%$ of households use their wealth to enrich themselves further through investments. That is, the households with assets in trust are not only wealthier than others, but they also have the kind of wealth that generates income: investments held in US private trusts generate at least $\$ 9.7$ billion annually in income, nearly tax free (Rosenmerkel, 2013). This use of trusts to hold financial investments is concentrated at the pinnacle of the socioeconomic spectrum: the top $1 \%$ of households have $38 \%$ percent of their assets in trust; the next $9 \%$ of households have $43 \%$ of their assets in trust (Wolff, 2012). This suggests the power of trusts to multiply socioeconomic inequalities in a financialized environment where wealth and power accrue primarily to investors (Cap-Gemini, 2014).

This is true not only among private individuals, but in the corporate world, where professional investors have used trusts to consolidate their organizational and economic power. In past decades, roughly coinciding with the rise of financialization, the trust's relative freedom from regulatory oversight has made it a very attractive vehicle for large-scale investing, such as bond issues, mutual funds, pension funds and hedge funds. While all of those investments can be organized through other structures, trusts are preferred for several reasons, including reduced transaction costs and flexibility concerning matters such as how creditors are to be repaid (Moffat, 2009). 
As a result, trusts permit investing to occur on a scale that would not otherwise be practical, streamlining investments and payouts better than the corporate form, and doing so with less regulatory friction. This has facilitated the growth of key areas of finance, such as the mutual fund industry. As Malkiel (2013) has pointed out, mutual funds in the USA managed less than $\$ 26$ billion in assets as of 1980 ; by 2010, the total value of assets in mutual funds had grown to $\$ 3.5$ trillion, representing a 135 -fold increase. While a number of forces drove the influx of capital, it is not often acknowledged how the trust structure made this growth possible, as well as profitable. By reducing transaction costs, the trust made collective investing a lucrative domain of finance; organizationally, it provided the tools that enabled millions of Americans to participate in the financial markets. This mass inflow of new investors was a crucial step in the financialization of the US economy: individuals who might not be able to afford more than a handful of stocks (at an average cost of $\$ 35$ per share) could suddenly invest across a broad spectrum of industries through the mechanism of mutual funds (Harrington, 2008). Trusts are thus implicated in 'the shift from passive savers to active investors [which is] associated with financialization' (Beaverstock et al., 2013, p. 843).

In this respect-facilitating a massive inflow of assets to collective investment vehicles like mutual funds-trusts have contributed so successfully to financialization that they have enabled the managers of these collective investments to amass enormous political and organizational power. These 'institutional fiduciaries', who manage collective investment trusts, 'now have the power to control much of corporate America. This phenomenon has been labeled "fiduciary capitalism"' (Rounds and Rounds, 2012, p. 36). In this sense, the trust form has proven to be a 'privileged site of accumulation' (Krippner, 2005, p. 181) for the managers of large investment pools.

The power that trusts give to investors in the contemporary financialized economy can be illustrated in part by the subprime mortgage crisis that underpinned the $2008 \mathrm{crash}$. The comparatively light regulation to which trusts are subject makes them convenient for use in high-risk, high-profit investments. Thus, when banks went in search of new ways to attract capital, they turned to the trust structure, using them to bundle assets like mortgages and resell them as investment vehicles (Langbein, 1995). Millions of individual mortgage obligations were poured into trusts, like ingredients into a casserole dish; the contents were then sliced into 'tranches' and sold to investors around the world.

This scheme, on which the whole subprime mortgage crisis was based, hinged on the divided-ownership concept that distinguishes the trust: while the trust owned all the mortgages as a group, the right to collect the mortgage payments could be parceled out to thousands of investors as 'beneficiaries' of the trust. This divided-ownership structure dramatically increased the profit potential of these securities by broadening the range of individuals and entities who could invest in them (Winnett, 2008). Unfortunately, this broad range, combined with the riskiness of the underlying securities, proved to be the undoing of the world financial system: the result was a 'contagion' of losses that spread as if transmitted by 'contaminated food' (Dodd and Mills, 2008, p. 14). Without trusts, there might have been no subprime mortgage crisis; because of trusts, the crisis spread globally. This underscores the trust's power to put investors at the center of the economy, albeit in a negative way.

Following the crisis, it was observed that banks and investment firms managed to privatize their profits while socializing the losses they incurred-offloading the costs of market participation onto taxpayers (Kristof, 2011). Less well-known is how private investors 
accomplished a similar feat through trusts. As the epigraph to this article suggests, trusts have become an essential tool for economic elites to protect financial wealth from the recurrent crises in capitalism (Franklin, 1933). This observation may explain the disparate impact of the 2008 crisis on private fortunes.

Due to the tax advantages and protections from creditors afforded by trusts, economic elites were actually able to benefit from the crisis, consolidating their power as investors. The wealthiest households-identified by Franklin and others (e.g., Wolff, 2012) as the primary users and beneficiaries of trusts-are now $45 \%$ wealthier than they were prior to the crisis; meanwhile, the median household still has not recovered all the wealth it lost in 2008 (Bricker et al., 2014; Rugaber, 2014). Likely mechanisms underlying this disparity in impact include the protections trusts provide from creditors and the state.

While elites lost money in the crisis just like everyone else (Cap-Gemini, 2014), their assets in trust were insulated: recall from Figure 1 that private express trusts (the primary form of trust used by individuals) can protect assets from seizure for payment of debts or taxes. ${ }^{8}$ So while many households saw their homes foreclosed on, or their other assets claimed by creditors, the wealthiest were often protected from this calamity by having their homes and other components of their family fortunes held in trusts (Paik, 1998; Bricker, et al., 2014). Not only did they get to keep these assets, but they could use them as sources of supplemental income and collateral, such as by renting out the property held in trust (thus literally becoming rentiers) or offering their beneficial interest in the trust assets as security against a bank loan. Thus, trusts created a private safety net for the wealthy andperhaps more importantly-provided a means to access additional credit and to make new investments.

Having multiple means of access to capital—both in their own name and through trusts (de Willebois et al., 2011)—gave global elites the opportunity to acquire assets at deeply discounted prices after the crisis. Because of the special protections afforded to them by having their assets in trust, the world's wealthiest people could buy when everyone else was selling; this maximized their profits in the run-up of securities and real estate prices during the recovery (Irwin, 2014). So while most Americans own significantly fewer financial securities than they did before 2008 , the top $10 \%$ of households by wealth actually own more securities than before and are consequently wealthier than ever (Wolff, 2012).

As this example suggests, trusts confer special advantages for wealth accumulation to both private and commercial users. By offering privileged profit opportunities, along with special protections from risk, they have enabled investors to consolidate their power. This has contributed to the spread of financialization in the economy.

\subsection{Global spread of the Anglo-American approach to finance}

Financialization has been portrayed in the scholarly literature as 'a decidedly AngloAmerican phenomenon' (van der Zwan, 2014, pp. 114-115; see also Deeg and O'Sullivan, 2009, p. 738). As this phenomenon has propagated worldwide, trusts have formed an

8 This is particularly the case with discretionary trusts, also known as 'spendthrift trusts' because of their asset-protection properties. In a discretionary trust, a beneficiary only receives assets at the discretion of the trustee. Thus, if creditors demand that the beneficiary pay debts from trust assets, the trustee can simply refuse to make a distribution, blocking access to the trust fund. Beneficiaries can thus truthfully say that they cannot pay debts with funds belonging to the trust. 
inextricable part of the package. The stage was set by the global reach of British colonialism in the 18th and 19th centuries, which imposed the Common Law tradition on each imperial territory. This meant that the trust diffused with the rest of the Common Law framework into every corner of the Empire. The remnants of that legacy can still be observed in today's leading offshore financial centers, most of which are current or former British territories, including Singapore, Hong Kong, the Channel Islands, Bermuda, the Cayman Islands and the British Virgin Islands. These jurisdictions are now where many trusts, particularly in corporate finance, are domiciled, and where most of the innovations in the law and design of trusts are taking place (Parkinson, 2004).

Onshore, many of the world's great financial powers-such as the USA and other former British colonies-have also enshrined the trust as part of their own adaptations of the Common Law tradition. As one scholar put it nearly a century ago, in a review of British imperial power,

Wherever the Common Law penetrates, it carries with it its younger sister Equity along with the whole apparatus of Trusts and the distinction of legal and equitable ownership...There is only one thing to do-to capitulate. (Lee, 1915, pp. 99-100).

Perhaps more surprising are the inroads trusts made into legal systems outside the Common Law jurisdictions. For example, while European Civil Law regimes did not formally acknowledge the validity of trusts until recently (see below), they have long offered de facto recognition: 'The English trust has everywhere planted itself like a cuckoo in the nest of the Civil Law, and this is, as you will agree, a remarkable circumstance' (Amos, 1937, pp. 1263-1264). ${ }^{9}$ What makes this 'remarkable' is that Civil Law does not recognize the concept of divided ownership on which trusts depend for their existence.

The circumstances of the trust's spread and endurance become even more remarkable when it is considered that trusts originated in the Middle Ages (Harrington, 2012a). During this period, when many landowners departed England to participate in the Crusades, and wills were not recognized as a valid means of transferring property, nobles risked losing their estates while they were in the Holy Land. Since women and minors could not own property, the absence or death of the adult male landowner left estates vulnerable to being usurped. And even if the landowner left behind an adult male heir, the taxes due to the King on the transfer of the estate could be ruinous.

Trusts solved all these problems at once by allowing the original landowner to transfer title to his property to a trusted friend or relative-the trustee. The original landowner or his family continued to occupy the property as beneficiaries, but by making the transfer while the settlor was still alive, no tax was due. If the original landowner died in the Crusades, the

9 The cuckoo lays its eggs in the nests of other birds, to be raised along with the birds' own young. Lepaulle (1927, p. 1126) explained the spread of the Common Law trust into Continental European practice based on the versatility and efficacy of the structure:

Trusts have now pervaded all fields of social institutions in Common Law countries. They are like those extraordinary drugs curing at the same time toothache, sprained ankles and baldness, sold by peddlers on the Paris boulevards; they solve equally well family troubles, business difficulties, religious and charitable problems. What amazes the skeptical civilian is that they really do solve them! 
property could still be transferred to his adult male heir tax-free, since the trustee and titleholder were still alive. If there were no adult heir, the trustee was to hold the property in trust for the benefit of the original owner's wife and minor children, as long as they lived. While there were instances of fraud by trustees who seized lands for their own benefit, for the most part the system worked well, since it depended upon social closure among a tightly-knit group of landed nobles (Marcus, 1983; Harrington 2012a). Trusts were taken up almost as an act of class solidarity against tax and inheritance laws that threatened to dissipate dynastic fortunes.

With the transition from feudalism to capitalism, landed wealth was increasingly superseded by financial assets; in this context, trusts provided elites with a means of control that was not easily duplicated through contracting or incorporation. The key to the trust's enduring popularity was its flexibility in design, allowing it to keep pace with changes in the nature of capitalism itself:

Although feudal law no longer needs evading, the trust has endured because it has changed function. The trust has ceased to be a conveyancing device for holding freehold land and has become instead a management device for holding financial assets (Langbein, 1995, p. 637).

Rather than the corporate structure replacing trusts, firms began using trusts themselves as a mainstay of structured finance (Parkinson, 2005). The spread of the trust has created an efficient system of capital transfers for both individuals and corporations, realizing the project of global financial coordination begun by the British in the 18th and 19th centuries. But rather than state-led coordination, the system is tied together by 'globalized localisms' (Jensen and Santos, 2000) like the Anglo-American trust.

It is particularly noteworthy that in the past few decades-coinciding with the rise of financialization - the trust has been formally recognized and even adopted into law by countries that were never part of the British Empire. This suggests that trusts, which are considered 'the most distinctive achievement' (Maitland, 2011 [1909]) of the Common Law traditions of the UK and USA, may be a factor in the worldwide propagation of the AngloAmerican system of financialization. The adoption of trusts by states that have not adopted the Common Law regime as a whole has been driven by the pressure of private and corporate capital moving with decreasing regard for national boundaries: this capital, seeking 'new global circuits of accumulation' (Robinson, 2001, p. 173) requires the trust structure to achieve maximum mobility with minimal regulatory friction. As one legal scholar observed early in the era of financialization, 'with the increasing mobility of capital and persons, more and more trust assets, beneficiaries and trustees are to be found in non-trust States [e.g., countries whose legal systems do not recognize the trust concept]' (Hayton, 1987 , p. 260). Thus, in addition to the spread of trusts through colonialism-and the resultant incorporation of trust law through adoption of Common Law frameworks outside of England-a second factor has contributed to their propagation: the sheer force of private and corporate capital seeking global mobility.

This resulted in several crucial developments in the diffusion of the trust worldwide. The first was the adoption of the 1985 Hague Convention on the Law Applicable to Trusts and Their Recognition. The timing of this agreement occurred in the early stages of financialization, and likely played a role in its global spread. The signatories to the Convention included numerous countries that had never formed part of the British Empire, including Italy, 
France, Luxembourg and the Netherlands. Their signatures represented a significant step in the worldwide spread of financialization, providing the first formal recognition in Civil Law countries of the validity and enforceability of trusts created in Common Law jurisdictions. This did not mean that the signatory countries incorporated trusts into their legal regimes, but the move did recognize the rights of residents in those countries to benefit from trust assets, and for property in those Civil Law countries to be put into trust. The latter move was a crucial step in providing the capital mobility characteristic of financialization, as it permitted an asset located in a nation governed by Civil Law to be legally owned by a trust in a Common Law jurisdiction. This move was welcomed by international financiers, such as former Yukos Oil chairman Mikhail Khodorkovsky, who attempted to save his company from seizure by the Putin government by putting majority of the shares in a Guernsey trust; unfortunately, Civil Law Russia was not a signatory to the Hague Convention, and Khodorkovsky's move was unsuccessful (Sixsmith, 2010).

However, two of Russia's neighbors-Japan and China-have made very successful inroads into the global financial system by adopting trusts directly into their national legal systems. China began this effort relatively early in the history of contemporary financialization: legislators began drafting its first trust law in 1993 with the explicit aim of making the country a successful competitor in modern global finance. As one study put it, 'Lawmakers hoped that the Trust Law would ... modernize China's financial infrastructure and provide a platform for further development of ... private investment, such as securities investment funds, occupational pension funds, collective investment trusts, etc.' (Lee, 2009, p. 655). The ultimate adoption of the Trust Law in 2001 was instrumental in financializing the Chinese economy-facilitating the privatization of state-owned enterprises and the creation of investment funds, and the country's rise to become one of the most attractive global centers for foreign investment (Hunter, 2014).

In Japan, the Act on Investment Trusts passed in 2000 has opened the civil law country to financialization with great success. Among other things, it created a huge market-both international and domestic-for property development through Real Estate Investment Trusts. This market sector has exploded in value: with over $\$ 102$ billion in assets, it is one of the most successful real estate markets in the world (Association for Real Estate Securities, 2013). This use of trusts for commercial purposes was the linchpin in the Japanese government's strategy of using financialization to overcome the country's economic crisis: 'Japan has been aiming to transform itself into an investment-oriented society. In this regard, J-REITs [Japanese Real Estate Investment Trusts] have made a significant contribution' (Tamura, 2012). Real estate trusts play a role in financialization by providing greater profit-making opportunities to both developers and investors than are available through other means of property development: for example, they offer a way for developers to raise capital at lower cost (including both interest expenses and compliance costs) than through bank loans, and reward investors with higher yields than are available through bonds (Fuchita and Litan, 2007). Following suit, China just created its first Real Estate Investment Trust in May 2014 (Ang, 2014).

While the trust has spread globally, far beyond the reaches of the British Empire, the UK and its territories retain their primacy as centers of trust activity. Though most new wealth is being generated outside of Europe and North America, much of it returns to those traditional centers of trust activity at some point (White, 2014). This is driven by the quest for stability: 'Eastern Europe, the Middle East, North Africa and Russia are all areas of political instability and/or high liquidity ... they are therefore key markets for wealth-management 
services ... whichever market we're talking about, there's invariably a London connection' (Marr, 2014, p. 75). In other words, most of the world's wealth passes through London at some point to benefit from wealth-management services, in which the creation and management of trusts play a significant role.

This is a third way that trusts have spread the Anglo-American model of finance worldwide: through the UK's ongoing dominance of the market for trust services, capital from all over the world gravitates to London. In what the Economist recently described as 'a bitterly competitive market' among jurisdictions providing trust services (2013), the number of trusts and the extent of assets under management in each locale are typically kept under wraps, partly to avoid bringing unwelcome scrutiny to themselves and their clients. Some sense of the scope of the phenomenon is suggested by the finding that trusts hold at least $\$ 10$ billion in UK property investments by foreigners-including the many multimilliondollar London properties owned by Russians and Middle Easterners seeking a safe haven for their personal fortunes (Leigh et al., 2012).

The preeminence of the UK in this international competition to dominate the trust business is discussed publicly as a matter of national strategy. For example, the former British finance minister reported a conversation in which his counterpart from Luxembourg (a long-standing competitor in the trust services industry) acknowledged that 'All our bankers and financial lawyers [in Luxembourg] say that if you really, really want to hide money, go to London and set up a trust' (MacShane, 2009).In this sense, trusts have been instrumental in driving the financialization of the British economy, as well as disseminating the AngloAmerican model of finance through three mechanisms: colonialism, recognition and adoption of the trust by countries untouched by British colonial power, and finally by the City of London's institutional dominance of the international competition for trust services.

\subsection{Autonomy of finance from the nation-state}

As van der Zwan (2014, p. 100) has observed, financialization is characterized in part by the increasing autonomy of finance from the political economy of nation-states. As the previous section suggests, trusts have for centuries served as tools for wealthy elites to protect their assets from taxation and other exercises of state authority. If state power consists in its ability to tax effectively (Goldstone, 1991; Li, 2002), then trusts have long posed a significant threat to that power.

What is new in contemporary finanancialization is the use of the trust structure to transcend the nation-state system entirely. This has occurred via two key mechanisms: fortifying the 'shroud of secrecy' (Shaxson, 2011, p. 42) surrounding trusts, and creating hypermobility for trusts and the capital they contain (Beaverstock et al., 2004). Through these two means, trusts have been used to advance a far more ambitious agenda than tax avoidance (Harrington, 2015, 2016). In effect, they have enabled finance practitioners and capital to escape the 'sovereign national cage' (Palan, 2002, p. 168)

Since most of the assets contained in private and commercial trusts are financial (Parkinson, 2005; Bricker, et al., 2014), this expansion in the use of discretionary trusts effectively puts that realm of finance beyond the reach of the state's legal apparatus-or rather, selectively exploits the conflicts and gaps among national legal systems to achieve autonomy from all of them. This development in trust practice provides 'freedom from democratic restraint' (Monbiot, 2012), and contributes to the increasing detachment of finance from subjugation to state authority. 
Concurrent with the rise of financialization, the late 20th century 'saw a flowering in discretionary trusts intended to make the beneficial owners of trusts unindentifiable, so that no-one will owe taxes on those assets and no-one's creditors will be able to collect their debts therefrom' (Hofri, 2015, p. 43). These structures-also known as asset protection trusts-make it difficult, if not impossible, to subject trusts or their beneficiaries to state power: that is, to enforce tax obligations or accountability to creditors, heirs and litigants. Trusts explicitly designed to thwart such obligations were pioneered by the Cook Islands, a remote jurisdiction in the South Pacific, in their 1989 International Trusts Act. Among other things, this Act states that assets held in Cook Islands trusts will not be subject to any judgment by a foreign court, and cannot be accessed for punitive damages or payments to creditors. In effect, this puts such trusts 'outside the rule of law' (Wayne, 2013a).

These trusts are designed not just for tax avoidance, but for law avoidance in general. Providing firms and wealthy individuals with freedom from state power has proved to be a highly successful (and highly lucrative) strategy. Notable cases include Baroness Carmen Thyssen-Bornemizsa of Spain, whose private art collection—valued at billions of dollars-is owned through trusts in the Cook Islands and other jurisdictions (Kandell, 2002; Cabra and Hudson, 2013), and the late Baron Elie de Rothschild of France, who created a network of more than 20 Cook Islands trusts between 1996 and 2003 alone. The Cook Islands is particularly popular among Americans, such as the Cordish real estate dynasty of Baltimore (\$116 million in Cook Islands trust assets) and Denise Rich, ex-wife of disgraced trader Marc Rich: her Cook Islands trust contained \$100 million in assets, ranging from her 157foot yacht, to her Learjet and her Swiss bank account.

This popularity stems in part from the jurisdiction's unbroken track record of stonewalling the legal authority of other nations. To date, no effort to break a Cook Islands trustdespite numerous attempts by the US government, among other powerful states-has been successful. Meanwhile, the six registered trust companies in the Cook Islands generate $8 \%$ of the island's $\$ 300$ million GDP, after tourism and ahead of fishing (Wayne, 2013b). To compete for their own share of these fees, at least 25 other countries have followed the Cook Islands in creating asset protection trust legislation of their own.

As this example suggests, the laws pertaining to trusts serve mainly to protect the structures and their beneficiaries. In contrast, few laws-if any-exist to protect the public interest from the use of trusts, even when it comes to preventing them from being used to facilitate money laundering and corruption (Hofri, 2015). As one recent study of international financial crime concluded, 'Trusts ... prove such a hurdle to investigation, prosecution (or civil judgment) and asset recovery that they are seldom prioritized in investigations' (de Willebois et al., 2011, p. 45).

The fluidity of movement that trusts provide has been another key factor in creating this autonomy for financial activity. Trusts facilitate what Arrighi (1994, p. 2) identified as 'the tendency since 1970 ... toward greater geographic mobility of capital.' This mobility was catalyzed by the relaxation of currency controls in many countries during the 1960s, followed by a dramatic rise in taxes (Genschel, 2005). These developments created a motive for finance to increase its autonomy from the nation-state; trusts provided the means to achieve this end.

Trusts' increasingly global recognition (see Section 3.2) allows capital to move quickly and conveniently across borders. This is crucial because 'in an economy that is not only capitalist but financialized ... capital must be as mobile as possible' (Sayer, 2015, p. 240). Assets held in trust need not be subject to any particular jurisdiction: instead, trustees can 'shop 
around' in 'the global "market for laws"' (Frankel, 1998, p. 257), seeking the legal and financial regimes that best suit their interests. This is built into many trusts in the form of 'flee clauses', which allow trusts and their assets to shift from one jurisdiction to another automatically whenever they are threatened by legal action (Pusceddu, 2014). This means that while the law may have a long arm, trusts can easily slip through its fingers. The modern instantiation of the trust for asset protection is thus 'an innovation that allows actors to greatly minimize, if not fully escape, centralized country laws, in favor of alternative legal systems' (Quack, 2007, p. 643).

For example, Carmen Thyssen-Bornemisza keeps her art collection in trusts in the Cook Islands and elsewhere because the structures offer 'maximum flexibility' when she moves the works across international borders for exhibition or sale (Cabra and Hudson, 2013). Ordinarily, the works she owns-including paintings by Van Gogh and Manet-would be subject to tight legal controls restricting their movements; art of that caliber is often considered not just private property, but part of a nation's patrimony, subject to the UNESCO Convention of 1970 on the Means of Prohibiting and Preventing the Illegal Import, Export and Transfer of Ownership of Cultural Property (Weber, 2006). Putting the art collection in trust avoids what Thyssen-Bornemisza's lawyer calls the 'nightmare' of these national legal restrictions: 'It's convenient', he said. 'You have more freedom to move the assets, not just buying or selling, but also circulation' (Cabra and Hudson, 2013). By increasing the mobility of her wealth, the trust structure also maximizes Thyssen-Bornemisza's opportunities to make a profit, allowing her to sell the works to the highest bidder, anywhere in the world.

This increasing autonomy of capital relative to the law seems to be what is meant by the observation that 'The declining ability of the national state to intervene in the process of capital accumulation ... reflects the newfound power that transnational capital acquired over nation-states' (Robinson, 2001, p. 169). This article extends that insight by specifying the trust as a means by which capital becomes transnational and financialization expands globally. Among other things, trusts allow financial actors to attend to national boundaries and laws only when it is convenient for them. This is true both of wealthy individuals and corporate entities. As a US Congressional Committee put it in their report on Enron, the firm's use of trusts allowed company to treat 'regulations as a one-way street, to be relied upon when supportive of the desired return position [e.g., profit opportunity] and to be disregarded when contrary to such a position' (US Congress, 2003, p. 260).

Finally, those who downplay the rise of finance worldwide often point to the lack of formal institutional coordination among states, or what Krippner diplomatically terms 'the rather limited extent to which international economic integration is in evidence' (2005, p. 202). But exploitation of this fragmented system may be crucial to the growing power of financialization. This suggests that those who doubt the ascendancy of global finance vis-àvis the power of the state (Krippner calls them 'globalization skeptics') may be looking in the wrong place for the 'new world order'. It has not taken the form of an international 'super state' to govern global finance, but of a set of practices-such as the private and corporate use of trusts- that exploit and thrive on the divisions in the old Westphalian order.

\section{Discussion}

Trusts provide a legal structure that has enabled financialization to spread and consolidate power globally. As a result of its 'great elasticity and generality' (Maitland, 1936, p. 129), 
the trust outlasted the original conditions that gave rise to its creation in the Middle Ages. Over the centuries, the practical use of trusts has evolved continuously to meet the changing demands of capitalism. Indeed, what Braudel once observed of capitalism - that it persists due to 'its unlimited flexibility, its capacity for change and adaptation' (1982, p. 433, emphasis in original)—could equally well be said of the trust structure. It has developed from its origins as a device for holding title to landed wealth to become a vehicle for active investment in securities, making it a mainstay of contemporary asset protection and structured finance (Langbein, 1995).

However, one distinctive feature of trusts has remained unchanged over 700 years: the concept of divided ownership. The notion of detaching the benefits from the responsibilities of owning property makes possible many of the trust's legal 'tricks' (Moffat, 2009). This also provided a ready-made tool to serve the interests of financialization: when capital mobility was on the rise (Arrighi, 1994), trusts were there to facilitate nearly frictionless international asset transfers; when new sources of profit maximization were sought (Krippner, 2011) trusts offered a distinctive way to cut tax and regulatory compliance costs. Trusts did not create financialization, but rather coincided with it, accelerating its spread as a global phenomenon.

It achieved this in three ways: by contributing to the economic centrality of investors; by representing and facilitating the imprint of the Anglo-American tradition on finance; and by providing financial actors and assets with greater autonomy from the nation-state system. As detailed in the previous sections, these consequences stemmed from an iterative series of modifications in international law and the trust structure itself, in response to the demands of an increasingly financialized economy. These modifications began soon after the rise of financialization in the late 1970 s, and continue to the present day.

The most recent developments have involved legislation allowing trusts to take on many of the most attractive features of the corporation as a legal structure. This new-andimproved version of the trust offers to further advance financialization, particularly in the realm of profit maximization. In this respect, two changes are particularly significant: the growth of limited liability for trustees, and the lifting of traditional time limits on trusts' lifespan (known as the Rule Against Perpetuities).

Traditionally, trustees have been subject to tight limits on what they could do with trust assets; the law emphasized asset protection over growth, and held trustees personally responsible for any losses incurred to wealth held in trust (Langbein, 1997). This discouraged profit-seeking, and made trustees 'economically celibate' (Hall, 1973, p. 282). The change in liability rules in some jurisdictions has increasingly given trustees the kind of limited liability protections enjoyed by corporate officers, freeing trustees to engage in more high-risk/high-profit investments (Hofri, 2015).

The elimination of the Rule Against Perpetuities has also favored profit maximization for trusts, albeit in a different way: by expanding the special tax protections trusts enjoy relative to corporations. Historically, a major disadvantage for trusts relative to corporations was that while corporations could exist in perpetuity (at least in theory), trusts had to dissolve about a century after they were created. But starting in the 1980s, some jurisdictions began eliminating that time limit on trusts, allowing the wealth they contain to grow forever without 'interference' by tax authorities or creditors (Hofri, 2015). This appropriation of corporation-like features by trusts proved to be extremely attractive to firms and wealthy individuals: within the USA between 1997 and 2003, 'roughly \$100 billion in trust funds have moved [jurisdictions] to take advantage of the abolition of the Rule' against 
perpetuities; each jurisdiction that abolished the Rule saw a $20 \%$ increase in trust assets under management during that 6-year period (Sitkoff and Schanzenbach, 2005, p. 356).

As these recent developments suggest, trusts not only facilitate the spread of financialization but are changed by it. A recent legal text observed that 'the trust as we know it today is the product of centuries of evolution' (Rounds and Rounds, 2012, p. 34). The pace of this evolution has clearly accelerated in the decades since financialization began. After centuries of slow adaptation, the trust has undergone an unprecedented series of modifications in response to the needs of a financialized economy (Hofri, 2015).

Some of the key events in this process have been discussed in the text; a few othersshown in Table 2-bear mentioning to give a sense of the continuity of this evolution over the past decades. The timeline starts with the adoption of the Hague Convention on Trusts, which initiated the spread of formal legal recognition of trusts in Civil Law countries. This included the eventual passage of trust legislation in China and Japan, two of the biggest economies in the world, as part of an explicit effort by policy-makers in those Civil Law countries to promote financialization (see Section 3.2). Concurrently in Common Law jurisdictions, a series of innovations leveraged the flexibility of trust law to confer additional privileges on trusts as sites of capital accumulation: these included new exemptions from taxes and lifespan limits onshore, as well as additional asset protection and privacy safeguards offshore.

As this timeline suggests, trusts exemplify the notion of a 'globalized localism' (Jensen and Santos, 2000). Having emerged from a very different era and a set of circumstances particular to medieval English landowners, the trust has undergone series of adaptations around the globe. This process has accelerated in recent decades under pressure from growing financialization, turning the trust into one of the most powerful tools available for profit maximization and capital mobility. For both corporations and wealthy individuals, trusts play a central role in 'lubricating the ... capital markets' worldwide (Rounds and Rounds, 2012, p. 36).

\section{Conclusion}

This article identifies the trust as a key strategic tool in the expansion of global financialization. It argues that trusts have been linked to financialization's spread in three ways: by placing the figure of the rentier-investor at the center of the global economy; by facilitating the dominance of the Anglo-American tradition in finance worldwide; and by increasing the autonomy of finance vis-à-vis the nation-state. In addition, the study extends Krippner's work in two ways: by showing how private capital is implicated in this system, and by arguing that trusts should be considered alongside firms among the 'privileged sites of accumulation' (Krippner, 2005, p. 181) in the financialized economy.

Unlike corporations, trusts are private arrangements: as a result, they are free from public registration and most of the regulatory burden imposed on firms. The privacy surrounding trusts is key to their scholarly interest, as well as to their practical appeal for corporations and high-net-worth individuals. In a political economy characterized by growing market regulation (Seabrooke, 2011), trusts inhabit a distinctive space that resists transparency and governance. Although they have been largely overlooked in the scholarly literature, trusts offer unusual benefits in terms of secrecy, flexibility, profit maximization, and ease of international mobility. Figure 1 and Table 1 crystallize trusts' special features through a typology and through comparison to the better-known corporate structure. These 
Table 2. Major events in the evolution of trusts under financialization

\begin{tabular}{|c|c|c|}
\hline Year & Event & Significance \\
\hline 1985 & $\begin{array}{l}\text { Hague Convention on Trusts } \\
\text { signed }\end{array}$ & $\begin{array}{l}\text { As detailed in Section 3.2, this vastly expanded formal } \\
\text { recognition and acceptance of the trust structure in } \\
\text { Civil Law countries. }\end{array}$ \\
\hline 1986 & $\begin{array}{l}\text { US government grants special } \\
\text { tax exemptions to private } \\
\text { trusts }\end{array}$ & $\begin{array}{l}\text { As private ownership of stocks, bonds and other } \\
\text { securities grew, legislators changed the tax code to } \\
\text { make trusts a more attractive structure to hold this } \\
\text { wealth (Sitkoff and Schanzenbach, 2005). }\end{array}$ \\
\hline 1989 & $\begin{array}{l}\text { Cook Islands Asset Protection } \\
\text { Trusts Law }\end{array}$ & $\begin{array}{l}\text { As detailed in Section 3.3, this innovation in the legal } \\
\text { protections afforded to trusts accelerated the } \\
\text { growing autonomy of finance from the state. The } \\
\text { move proved so effective and profitable that } 25 \\
\text { other jurisdictions passed similar laws. }\end{array}$ \\
\hline 1993 & $\begin{array}{l}\text { China begins drafting its trust } \\
\text { law }\end{array}$ & $\begin{array}{l}\text { As detailed in Section } 3.2 \text {, Chinese lawmakers saw this } \\
\text { as a major step in modernizing the nation's financial } \\
\text { system. The law, ultimately passed in } 2001 \text {, was also } \\
\text { a significant force in financializing the Chinese } \\
\text { economy, dramatically broadening opportunities for } \\
\text { private investment and profit. }\end{array}$ \\
\hline 1995 & $\begin{array}{l}\text { Delaware repeals Rule } \\
\text { Against Perpetuities }\end{array}$ & $\begin{array}{l}\text { This began the process by which trusts took on many of } \\
\text { the most attractive features of corporations, while } \\
\text { retaining trusts' own distinctive advantages. The } \\
\text { repeal of the Rule proved so popular that the } \\
\text { majority of other US states followed suit. }\end{array}$ \\
\hline 1997 & $\begin{array}{l}\text { Cayman Special Trusts } \\
\text { Alternative Regime } \\
\text { (STAR) created }\end{array}$ & $\begin{array}{l}\text { Cayman's Special Trust Alternative Regime (STAR) law } \\
\text { eliminated the need for a trust to have } \\
\text { beneficiaries-another step in the co-optation of } \\
\text { characteristics of the corporate structure, making } \\
\text { trusts more convenient for use in commercial invest- } \\
\text { ment. In particular, this move was instrumental in } \\
\text { allowing the hedge fund industry to grow and attract } \\
\text { a broader international investment base (Strachman, } \\
\text { 2008). }\end{array}$ \\
\hline 2000 & $\begin{array}{l}\text { Japan's Act on Investment } \\
\text { Trusts }\end{array}$ & $\begin{array}{l}\text { As detailed in Section 3.2, the adoption of the trust } \\
\text { structure in this civil law country financialized the } \\
\text { Japanese real estate market and created a } \\
\text { multibillion-dollar investment industry. }\end{array}$ \\
\hline 2003 & $\begin{array}{l}\text { British Virgin Islands Special } \\
\text { Trusts Act (VISTA) } \\
\text { created }\end{array}$ & $\begin{array}{l}\text { This law made it easier for trusts to own corporate } \\
\text { entities by removing trustees' liability to supervise } \\
\text { the underlying company. This has made the VISTA } \\
\text { trust particularly popular for structuring bond issues } \\
\text { (Duckworth, 2007). }\end{array}$ \\
\hline
\end{tabular}


features-particularly the split-ownership model—have helped trusts endure over the centuries to become the basis of structured finance in firms, as well as of estate planning and asset protection for high-net-worth individuals.

As a privilege of the rentier class, trusts contribute to the growing importance of investors in the economy. The original rentiers-feudal landowners- used trusts to avoid their tax obligations to the king, and to consolidate their economic power against state authority (Harrington, 2012a). Contemporary investors-rentier capitalists-use trusts to serve similar purposes, but also to shelter their wealth from the risks of the financial markets. In modern use, trusts create exceptional opportunities for profit and the accumulation of new wealth. This extends not only to individuals, but to the corporations who have taken up trusts as a core element of their structured finance strategies. This is also true of entire political economies, such as those of China and Japan, which have grown significantly following their adoption of this element of the Anglo-Saxon financial model. In this process of global expansion, trusts have also adapted in form and usage to the changing demands of international finance (see Table 2). Thus, trusts have not only facilitated the growth of financialization, but have been changed by it. Future research should examine the mutually constitutive relationship between financialization and the evolution of trust structures and practices.

Finally, this study contributes the ongoing debate concerning the impact of globalization on the power of the state. The international adoption of trusts in structuring private and corporate wealth is consistent with the expectations of 'convergence theories' of financialization (Deeg, 2012), yet it has not led to convergence in the expected form. Instead of a multinational regime of formal financial regulations, trusts have propagated a set of concepts and practices that have become dominant worldwide. This includes the distinctive notion of divided ownership and the legal-financial 'tricks' (Moffat, 2009) it makes possible, which thrive on the gaps and conflicts among jurisdictions. By examining trusts' role in transnational capital transfers, this article seeks to contribute to the growing body of knowledge about the patterns of accumulation characteristic of financialization.

\section{References}

Amos, M. (1937) 'The Common Law and the Civil Law in the British Commonwealth of Nations', Harvard Law Review, 50, 1249-1274.

Ang, B. (2014, September 24) 'REITs Expand Reach in Asia,' Nikkei Asian Review, accessed at http://asia.nikkei.com/magazine/20140925-HONG-KONG-CORNERED/Markets/REITsexpand-reach-in-Asia on January 24, 2015.

Arrighi, G. (1994) The Long Twentieth Century, London, Verso.

Association for Real Estate Securities (2013) ARES J-REIT Report, 42, 1.

Batson, N. (2003) Second interim report of Neal Batson, court-appointed examiner. United States Bankruptcy Court, Southern District of New York. In: re: Chapter 11 Enron Corp., et al., Debtors, Case No. 01-16034 (AJG), Jointly Administered, January 21.

Blahous, C. and Reischauer, R. (2014) A Summary of the 2014 Annual Reports, Washington, DC: Social Security and Medicare Boards of Trustees, accessed at http://www.ssa.gov/oact/ trsum/ on January 20, 2015.

Beaverstock, J., Hall, S. and Wainwright, T. (2013) 'Servicing the Super-Rich: New Financial Elites and the Rise of the Private Wealth Management Retail Ecology', Regional Studies, 47, 843-849. 
Beaverstock, J., Hubbard, P. and Short, J. (2004) 'Getting Away with It? Exposing the Geographies of the Super-rich', Geoforum, 35, 401-407.

Becerra, J., Damisch, P., Holley, B., Kuman, M., Naumann, M., Tang, T. and Zakrzewski, A. (2011) Shaping a New Tomorrow: How to Capitalize on the Momentum of Change, Boston, BCG.

Boston Consulting Group. (2013) Global Wealth 2014: Riding a Wave of Growth, Boston, BCG.

Bowers, S. (2014, 15 December) 'Luxembourg Tax Whistleblower Says He Acted Out of Conviction', The Guardian, accessed at http://www.theguardian.com/world/2014/dec/15/lux embourg-tax-avoidance-whistleblower-conviction on August 28, 2015.

Bricker, J., Dettling, L., Henriques, A., Hsu, J., Moore, K., Sabelhaus, J., Thompson, J. and Windle, R. (2014) 'Changes in U.S. Family Finances from 2010 to 2013: Evidence from the Survey of Consumer Finances', Federal Reserve Bulletin, 100, 1-8.

Budría, S., Díaz-Giménez J., Ríos-Rull J.-V. and Quadrini, V. (2002) 'Updated Facts on the US Distributions of Earnings, Income, and Wealth', Federal Reserve Bank of Minneapolis Quarterly Review, 26, 2-35.

Cabra, M. and Hudson, M. (2013, April 3). 'Mega-Rich Use Tax Havens to Buy and Sell Masterpieces', International Consortium of Investigative Journalists, accessed at http://www. icij.org/offshore/mega-rich-use-tax-havens-buy-and-sell-masterpieces on December 2014.

Canadian Pension Board (2015) 'Our Performance', accessed at http://www.cppib.com/en/home. html on January 18, 2015.

Cap-Gemini (2014) World Wealth Report, Paris, Cap-Gemini.

Chancellor, E. (1999) Devil Take the Hindmost: A History of Financial Speculation, New York, Farrar, Straus and Giroux.

Chester, R. (1982) Inheritance, Wealth and Society, Bloomington, IN, Indiana University Press.

Conn, P. (2015) Transparency of Share Ownership, Shareholder Communications, and Voting in Global Capital Markets, Melbourne, Australia, Computershare/Georgeson.

de Willebois, E., Halter, E., Harrison, R., Park, J. and Sharman, J. (2011) The Puppet Masters: How the Corrupt Use Legal Structures to Hide Stolen Assets and What to Do About It, Washington, DC, World Bank.

Davies, J., Sandström, S., Shorrocks, A. and Wolff, E. (2008) The World Distribution of Household Wealth,' World Institute for Development Economics Research, Discussion Paper 2008/03, Helsinki, UNI-WIDER.

Deeg, R. and O’Sullivan, M. (2009) 'The Political Economy of Global Finance Capital', World Politics, 61, 731-763.

Deeg, R. (2012) 'Financialization and Models of Capitalism: A Comparison of the UK and Germany'. In Wood, G. and Lane, C. (eds) Capitalist Diversity and Diversity Within Capitalism, New York, Routledge, pp. 121-149.

Demick, B. (1990, October 7) 'The 400 Richest: Many Folks Try to Stay Off List', Philadelphia Inquirer.

Dodd, R. and Mills, P. (2008, June 14-18) 'Outbreak: U.S. Subprime Contagion', Finance \& Development.

Duckworth, A. (2007) 'Emerging Trends in the International Trust Arena', Trusts \& Trustees, 13, 3-6.

Dudden, A. (1957) 'Men Against Monopoly: The Prelude to Trust-Busting', Journal of the History of Ideas, 18, 587-593.

Easterbrook, F. and Fischel, D. (1993) 'Contract and Fiduciary Duty', Journal of Law and Economics, 36, 425-438.

Economist. (2013, August 24) 'Trawling for Business:The Gambia Looks to Join A Beleaguered Club', Economist, accessed at http://www.economist.com/news/finance-and-economics/ 21584019-gambia-looks-join-beleaguered-club-trawling-business on December 10, 2014. 
Edwards, C. (2005) 'Replace the Scandal-Plagued Corporate Income Tax With a Cash-Flow Tax'. In Niskanen, W. (ed.) After Enron: Lessons for Public Policy, Lanham, MD, Rowman \& Littlefield, pp. 283-334.

Fitch, S. (2003, November 24) 'Pritzker vs. Pritzker', Forbes.

Frankel, T. (1998) 'Cross-Border Securitization: Without Law, But Not Lawless', Duke Journal of Comparative and International Law, 8, 255-282.

Franklin, M. (1933) 'Administrative Law in the United States', Tulane Law Review, 19, 473-506.

Fuchita, Y. and Litan, R. (2007) New Financial Instruments and Institutions: Opportunities and Policy Challenges, Washington, DC: Brookings Institution.

Gauthier-Villars, D. and Ball, D. (2010, 8 July) 'Mass Leak of Client Data Rattles Swiss Banking', Wall Street Journal, accessed at http://www.wsj.com/articles/SB100014240527487046298045 75324510662164360 on August 28, 2015.

Genschel, P. (2005) 'Globalization and the Transformation of the Tax State', European Review, $13,53-71$.

Gerring, J. (2012). 'Mere Description', British Journal of Political Science, 42, 721-746.

Goldstone, J. (1991) Revolution and Rebellion in the Early Modern World, Berkeley, University of California Press.

Guinto, J. (2013, February) 'Sam Wyly’s \$550 Million Problem', D Magazine, accessed at http:// www.dmagazine.com/publications/d-magazine/2013/february/sam-wyly-fight-to-keep-familyfortune? single $=1$ on July 14, 2014.

Harrington, B. (2016) Capital without Borders: Wealth Management and the One Percent. Cambridge, MA: Harvard University Press.

Harrington, B. (2015, October 26) 'Inside the Secretive World of Tax Avoidance Experts', The Atlantic, accessed at http://www.theatlantic.com/business/archive/2015/10/elite-wealth-manage ment/410842/ on April 17, 2016.

Harrington, B. (2012a) 'From Trustees to Wealth Managers'. In Erreygers, G. and Cunliffe, J. (eds), Inherited Wealth, Justice, and Equality, London, Routledge, pp. 190-209.

Harrington, B. (2012b) 'The Sociology of Financial Fraud.' In Knorr-Cetina, K. and Preda, A. (eds), The Oxford Handbook of the Sociology of Finance, New York, Oxford University Press, pp. 393-410.

Harrington, B. (2008) Pop Finance: Investment Clubs and Stock Market Populism. Princeton, NJ, Princeton University Press.

Hall, P. (1973) 'Family Structure and Class Consolidation among the Boston Brahmins', PhD Dissertation, State University of New York, Stony Brook.

Hayton, D. (1987) 'The Hague Convention on the Law Applicable to Trusts and on Their Recognition', International \& Comparative Law Quarterly, 36, 260-282.

Hofri, A. (2015) 'The Stripping of the Trust: A Study in Legal Evolution', University of Toronto Law Journal, 65, 1-47.

Hughes, J. (2009, October 28) 'Concern Over Mortgage Master Trusts', Financial Times, accessed at http://www.ft.com/cms/s/0/04935560-c3f0-11de-8de6-00144feab49a.html\#axzz3KdiAALki on December 5, 2014.

Hunter, G. (2014, November 10) 'China Opens Door Wider to Foreign Investors', Wall Street Journal, accessed at http://www.wsj.com/articles/china-opens-doors-to-foreign-investment-instocks-1415604267 on January 19, 2015.

Investment Company Institute (2011, April 13) 'Retirement Assets Total \$17.5 Trillion in Fourth Quarter 2010', ICI Press Release, accessed at http://www.ici.org/pressroom/news/ret_10_q4 on January 14, 2015.

Jaffe, D. and Lane, S. (2004) 'Sustaining a Family Dynasty: Key Issues Facing Multi-Generational Business- and Investment-Owning Families', Family Business Review, 17, 5-18. 
Jenson, J. and Santos, B. (2000) 'Introduction: Case Studies and Common Trends in Globalizations'. In Jenson, J. and Santos, B. (eds) Globalizing Institutions: Case Studies in Regulation and Innovation, Aldershot, UK, Ashgate, pp. 9-26.

Kandell, J. (2002, April 28) 'Baron Thyssen-Bornemisza, Industrialist Who Built Fabled Art Collection, Dies at 81', New York Times, accessed at http://www.nytimes.com/2002/04/28/nyre gion/baron-thyssen-bornemisza-industrialist-who-built-fabled-art-collection-dies-81.html on January 19, 2015.

Kennickell, A. (2009) Ponds and Streams: Wealth and Income in the US, 1989 to 2007, Federal Reserve Board Finance and Economics Discussion Series, Washington, DC: Federal Reserve Board. accessed at http://www.federalreserve.gov/pubs/feds/2009/200913/200913pap.pdf on April 12, 2012.

Kolhatkar. S. (September 2006) 'Inside the Billionaire Service Industry.' The Atlantic.

Kopczuk, W. and Saez, E. (2004) 'Top Wealth Shares in the United States,1916-2000: Evidence from Estate Tax Returns', National Tax Journal, 57, 445-487.

Krippner, G. (2005) 'The Financialization of the American Economy', Socio-Economic Review, 3, 15 173-208.

Krippner, G. (2011) Capitalizing on Crisis: The Political Origins of the Rise of Finance, Cambridge, MA, Harvard University Press.

Kristof, N. (2011, October 1) 'The Bankers and the Revolutionaries', New York Times, p. SR11.

Labban, M. (2010) 'Oil in Parallax: Scarcity, Markets and the Financialization of Accumulation', Geoforum, 41, 541-552.

Labban, M. (2008) 'Contradiction of Space, Centralization of Capital, and the Hybrid State Oil Company: The Case of Russia', Human Geography, 1, 59-71.

Langbein, J. (1995) 'The Contractarian Basis of the Law of Trusts', Yale Law Journal, 105, 625-675.

Langbein, J. (1997) 'The Secret Life of the Trust: The Trust as an Instrument of Commerce', Yale Law Review, 107, 165-189.

Langbein, J. (2004) 'Rise of the Management Trust', Trusts \& Estates, 142, 52-57.

Lee, R. (2009) 'Conceptualizing the Chinese Trust', International \& Comparative Law Quarterly, $58,655-669$.

Lee, R. (1915) 'The Civil Law and the Common Law: A World Survey', Michigan Law Review, $14,89-101$.

Leigh, D., Frayman, H. and Ball, J. (2012, November 26) 'How Secret Offshore Firms Feed London's Property Boom', The Guardian, accessed at http://www.theguardian.com/uk/2012/ nov/26/secret-offshore-firms-fuel-london-property on January 20, 2015.

Lepaulle, P. (1927) 'Civil Law Substitutes for Trusts,' Yale Law Journal, 36, 1126-1147.

Levin, C. (2003, November 18) 'The US Tax Shelter Industry: The Role of Accountants, Lawyers, and Financial Professionals,' Statement by Senator Carl Levin before U.S. Senate Permanent Subcommittee on Investigations.

Li, R. (2002) 'Alternative Routes to State Breakdown: Toward an Integrated Model of Territorial Disintegration', Sociological Theory, 20,1-23.

Lund, S., Daruvala, T., Dobbs, R., Härle, P., Kwek, J.-H. and Falcón, R. (2013) Financial Globalization: Retreat or Reset? London, McKinsey \& Company.

MacShane, D. (2009, February 11) 'Show Us the Money', The Guardian, accessed at http://www. theguardian.com/commentisfree/2009/feb/11/tax-gap-corporate-money on July 12, 2014.

Maitland, F. (2011[1909]) Equity: A Course of Lectures, Cambridge, UK, Cambridge University Press.

Maitland, F. (1936) Selected Essays, Cambridge, UK: Cambridge University Press.

Malkiel, B. (2013) 'Asset Management Fees and the Growth of Finance', Journal of Economic Perspectives, 27, 97-108. 
Marcus, G. (1983) 'The Fiduciary Role in American Family Dynasties and Their Institutional Legacy'. In Marcus, G. (ed.) Elites: Ethnographic Issues, Albuquerque, NM, University of New Mexico Press, pp. 221-256.

Marcus, G. and Hall, P. (1992) Lives in Trust: The Fortunes of Dynastic Families in Late Twentieth-Century America, Boulder, CO, Westview Press.

Marr, R. (2014, November) 'Jersey: Riding the Tides of Change', STEP Journal, p. 75.

Monbiot, G. (2012, July 30). 'Our Economic Ruin Means Freedom for the Super-Rich', The Guardian, accessed at http://www.guardian.co.uk/commentisfree/2012/jul/30/economic-ruinsuper-rich-totalitarian-capitalism on 25 August.

Mukunda, G. (2014, June) 'The Price of Wall Street's Power', Harvard Business Review, accessed at https://hbr.org/2014/06/the-price-of-wall-streets-power on January 16, 2015.

Niskanen, W. (2007). After Enron: Lessons for Public Policy. Lanham, MD: Rowman \& Littlefield.

O’Toole, K. (1994, April 13-19) 'Northwest Defers Placement of Debt', Flight International, p. 18.

Outhwaite, R. (2006) The Rise and Fall of the English Ecclesiastical Courts, 1500-1860. Cambridge, UK: Cambridge University Press.

Paik, F. (1998, November 27) 'The Rich and Famous Use Trusts to Hide Ownership of Property', Wall Street Journal, accessed at http://www.wsj.com/articles/SB912140808262492000 on January 14, 2015.

Palan, R. (2002) 'Tax Havens and the Commercialization of State Sovereignty', International Organization, 56, 151-176.

Parkinson, M. (2004) Certificate in International Trust Management, Birmingham, UK, Central Law Training.

Parkinson, M. (2005) Diploma in International Trust Management: Trust Creation: Law and Practice, 3rd edn, Birmingham, UK, Central Law Training.

Parkinson, M. (2008) Trustee Investment and Financial Appraisal, 4th edn, Birmingham, UK, Central Law Training.

Piketty, T. and Zucman, G. (2014) 'Capital Is Back: Wealth-Income Ratios in Rich Countries,1700-2010', Quarterly Journal of Economics, 129, 1255-1310.

Pinçon, M. and Pinçon-Charlot, M. (1998) Grand Fortunes: Dynasties of Wealth in France. (Trans. Andrea Lyn Secara.) New York: Algora Publishing.

Plank, T. (2000) 'The Bankruptcy Trust as a Legal Person', Wake Forest Law Review, 35, 251-293. Pusceddu, P. (2014) 'International Trusts and Asset Protection', Trusts \& Trustees, 20, 739-745.

Quack, S. (2007) 'Legal Professionals and Trans-National Law Making: A Case of Distributed Agency', Organization, 14, 643-666.

Reid, B. (2006) ICI Fact Book, 46th edn, Washington, DC: Investment Company Institute.

Reid, B. (2014) Investment Company Fact Book, 54th edn, Washington, DC: Investment Company Institute.

Rosenmerkel, L. (2013) 'Split Interest Trusts, Filing Year 2011', Statistics of Income Bulletin, 40 Winter, 93-113.

Rounds, C. Jr. and Rounds, C.III (2012) Loring \& Rounds: A Trustee's Handbook, Alphen aan den Rijn, Netherlands: Wolters Kluwer.

Rudden, Bernard. (1981) 'Book Review of The Restatement of Trusts', Modern Law Review, 44, 610-611.

Saez, E. and Zucman, G. (2014) 'Wealth Inequality in the United States Since 1913: Evidence from Capitalized Income Tax Data,' Quarterly Journal of Economics. Forthcoming.

Sanders, F. (1791) An Essay on the Nature and Laws of Uses and Trusts, Including a Treatise on Conveyances at Common Law and Those Deriving Their Effect from the Statute of Uses. London, E. \& R. Brooke. 
Savchuk, K. (2014, May 8) 'Jury Finds Wyly Brothers Engaged In Fraud by Hiding Trades In Offshore Trusts,' Forbes, accessed at http://www.forbes.com/sites/katiasavchuk/2014/05/08/ jurors-weigh-fraud-charges-against-wyly-brothers-accused-of-13-year-scheme-of-secrecy/ on July 14, 2014.

Sayer, A. (2015) Why We Can't Afford the Rich. Bristol, UK: Policy Press.

Scott, A. (1922) 'The Trust as an Instrument of Law Reform', Yale Law Journal, 31, 457-468.

Seabrooke, L. (2011) 'Crisis of Confidence: International Organizations and Learning after the Financial Meltdown', Socio-Economic Review, 9, 574-579.

Sharman, J. (2006) Havens in a Storm: The Struggle for Global Tax Regulation, Ithaca, NY, Cornell University Press.

Shaxson, N. 2011. Treasure Islands: Tax Havens and the Men Who Stole the World, London, Random House.

Sitkoff, R. and Schanzenbach, M. (2005) 'Jurisdictional Competition for Trust Funds: An Empirical Analysis of Perpetuities and Taxes', Yale Law Journal, 115, 356-437.

Sixsmith, M. (2010) Putin's Oil: The Yukos Affair and the Struggle for Russia, New York, 15 Continuum.

Stebbings, C. (2007) 'Trustees, Tribunals and Taxes: Creativity in Victorian Law', Amicus Curiae, $70,2-8$.

Stewart, F. and Yermo, J. (2008) Pension Fund Governance: Challenges and Potential Solutions, OECD Working Papers on Insurance and Private Pensions, No. 18, Paris, OECD Publishing.

Stewart, H. (2012, 21 July). 'Wealth Doesn't Trickle Down-It Just Floods Offshore, New Research Reveals', The Guardian, accessed at http://www.guardian.co.uk/business/2012/jul/21/ offshore-wealth-global-economy-tax-havens on July 27, 2012.

Strachman, D. (2007) The Fundamentals of Hedge Fund Management, Hoboken, NJ: John Wiley \& Sons.

Tamura, K. (2012) Study Group on Growth of J-REIT Market, Working Paper, Tokyo, Association for Real Estate Securitization, accessed at http://www.ares.or.jp/en/pdf/Growth_ of_J-reitMarket.pdf on December 4, 2014.

UK Office for National Statistics (2011) Pension Trends, London, ONS.

US Congress Joint Committee on Taxation (2003) Report of Investigation of Enron Corporation and Related Entities Regarding Federal Tax and Compensation Issues, and Policy Recommendations. Report JCS-3-03. Washington, DC: General Printing Office, accessed on December 10, 2014 at http://www.gpo.gov/fdsys/pkg/GPO-CPRT-JCS-3-03/pdf/GPO-CPRTJCS-3-03-1-6-1-4.pdf.

van der Zwan, N. (2014) 'Making Sense of Financialization', Socio-Economic Review, 12, 99-129.

Wayne, L. (2013a, December 14) 'Cook Islands, a Paradise of Untouchable Assets', New York Times, accessed at http://www.nytimes.com/2013/12/15/business/international/paradise-ofuntouchable-assets.html? pagewanted=3\&_r=1\&pagewanted $=$ print.

Wayne, L. (2013b, December 16) 'Unlocking the Secrets of the Cook Islands', International Consortium of Investigative Journalists, accessed at http://www.icij.org/blog/2013/12/unlock ing-secrets-cook-islands on December 10, 2014.

Weber, M. (2006) 'The New Swiss Law on Cultural Property', International Journal of Cultural Property, 13, 99-113.

White, A. (2014, November 1) 'Is the Luxury London Housing Bubble About to Burst?' The Telegraph, accessed at http://www.telegraph.co.uk/finance/personalfinance/houseprices/ 11199948/Has-Londons-luxury-housing-market-hit-its-peak.html on January 19, 2015.

Winnett, R. (2008, August 5) 'Northern Rock in £3bn Bailout from Taxpayer', The Telegraph, accessed at http://www.telegraph.co.uk/finance/newsbysector/banksandfinance/2794277/ Northern-Rock-in-3bn-bail-out-from-taxpayer.html on December 1, 2014. 
Wolff, E. (2012) The Asset Price Meltdown and the Wealth of the Middle Class, Working Paper 18559, National Bureau of Economic Research.

Zelizer, V. (1996) 'Payments and Social Ties', Sociological Forum, 11, 481-495.

Zucman, G. (2015) The Hidden Wealth of Nations, Chicago, University of Chicago Press.

\section{Appendix}

\section{Selected uses of trusts as vehicles for collective investment}

\section{Bond issues}

In a bond issue, an organization (such as a firm or a government body) solicits loans based on an offer of collateral. This process can be organized in several ways, but the trust structure is often preferred for the sake of convenience; in some jurisdictions, such as the USA, use of a trust may be legally mandated. As a matter of convenience, the trust structure can save on transaction costs, since bondholders (those who buy a bond issue) may comprise a huge number of people, spread out all over the world, and their membership can change over time; transferring small amounts of collateral to each lender would incur significant costs for the issuer (Moffat, 2009). Therefore, the bond issuer typically streamlines the task by putting its loan collateral into a trust structure, overseen by a professional known as an 'indenture trustee'. This trustee acts a fiduciary for the beneficial interests of the lenders, ensuring that the company issuing the bonds remains in good financial condition. If the firm risks defaulting on its loan payments, the trustee has the power to foreclose on the collateral to pay the lenders (bondholders). The classified section of many financial newspapers contains many notices of such trusts; these notices, called 'tombstones' because their format resembles that of grave markers, are required in the USA. Figure 2 shows a March 1994 tombstone that appeared in the Wall Street Journal, notifying investors of a bond issue by Northwest Airlines, structured through a trust and backed by 10 aircraft as collateral (O’Toole, 1994).

\section{Mutual funds (also known as 'unit trusts')}

Mutual funds are collective investment vehicles in which trusts are used to pool the contributions of investors so that the funds can be deployed en masse to trade stocks and other securities, as the fund manager sees fit. Historically, they have been organized as trusts, but they can also take the form of corporations or partnerships (Reid, 2006). Trusts remain a common structure for mutual funds because they operate under fewer regulatory requirements than corporations, and in some jurisdictions provide liability protection similar to that of corporations. In addition, trusts can save transaction costs for mutual fund administrators in their dealings with investors by pooling all individual contributions into a trust. In return for cash contributions, the 'custodian trustee' issues 'units' of the fund to investors; this is why these investment vehicles are known as 'unit trusts' in most of the world. There are an estimated 5552 unit trusts in existence worldwide; in the US alone, unit trusts hold $\$ 87$ billion in assets under management (Reid, 2014).

\section{Pension funds}

Pension funds may be organized through a number of structures, including corporations, associations, foundations and trusts. Trusts are the most common form for pension funds in 


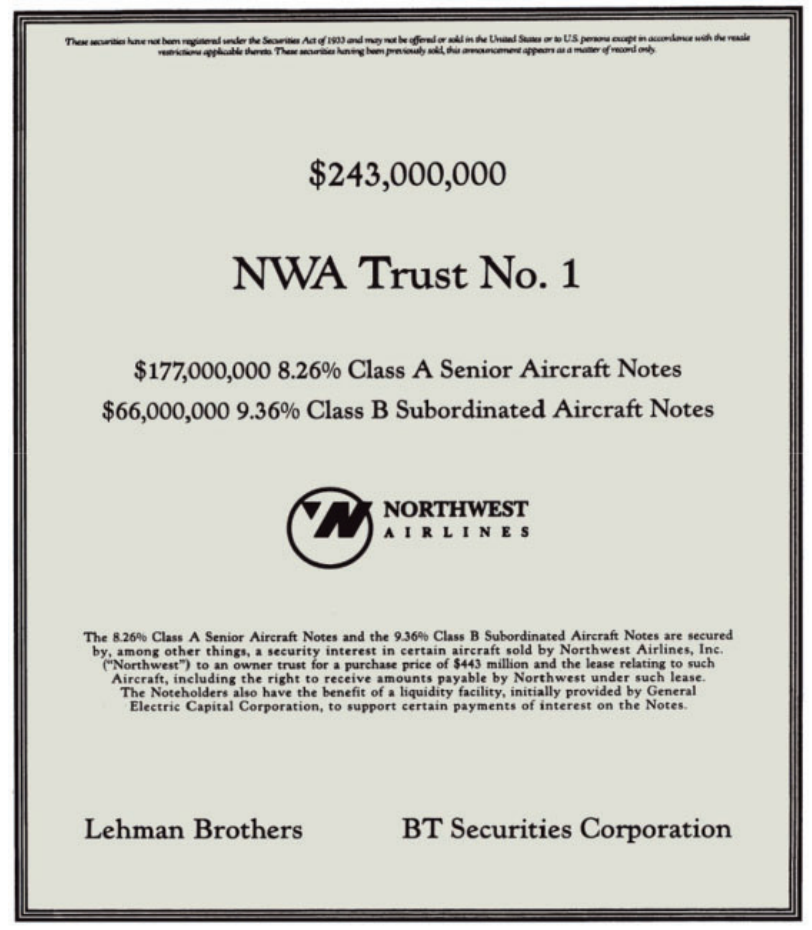

Figure 2. Tombstone notice showing trust used to issue bonds for Northwest Airlines.

(Stewart and Yermo, 2008). In this case, trusts are used to pool the contributions-by individual workers, their employers, or both-to a fund that can be invested en masse, rather than on an individual basis. This saves on transaction costs and provides economies of scale, such as the ability to buy large blocks of stock and enjoy a discount on brokerage fees. Examples of pension trusts in the public sector include the US Social Security program, which holds \$2.8 trillion in assets (Blahous and Reischauer, 2014). Canada's equivalent, the Canada Pension Plan, holds \$194 billion in a trust fund structure (Canadian Pension Board, 2015). In the private sector, Americans hold over $\$ 2$ trillion in employer-sponsored pension trusts (Investment Company Institute, 2011). In the UK, private sector pension trusts hold \$2.9 billion in assets (UK Office for National Statistics, 2011).

\section{Asset securitization}

Securitization trusts are used to hold pools of debt obligations, in which investors buy shares in order to partake of the income stream from debt repayments. Pooling such obligationssuch as mortgages, or credit card debt-into trusts allows financial institutions and firms to gain access to capital at a reduced cost, including reduced costs of regulatory compliance. For example, the UK bank Northern Rock pooled its mortgage obligations into a 'master trust' in order 'to find alternative funding sources, other than their retail deposit base and to benefit from reduced regulatory capital requirements' (Hughes, 2009). While limited liability 
corporations (LLCs) can also be used to structure asset securitization, trusts are often preferred for several reasons. These include protecting assets from taxation, and saving on compliance and transaction costs through the lower regulatory burden imposed on trusts versus alternative structures. In addition, trusts offer debt owners the ability to distance themselves financially and legally from the risks represented by that debt: moving legal ownership of the debts to a trust takes those risks 'off balance sheet' for the original owners, which may have the advantage of making the firm's financial position appear more secure than it really is. All three factors were motivations in Enron's fraudulent use of asset securitization trusts (Niskanen, 2005). Enron used FASITs (Financial Asset Securitization Investment Trusts) to avoid tax on the firm's foreign income, boosting the firm's bottom line-at least on paper. 10 US federal investigators found that Enron's use of trusts in two deals generated \$242 million in tax deductions for the firm in 1999 and 2000 alone (Edwards, 2005). 